\title{
Automated Internal Energy Calibration by OnTheFly for AGR-5/6/7
}

INL ART Program

Edward L. Reber

Dawn M. Scates

Ryan G. Fronk

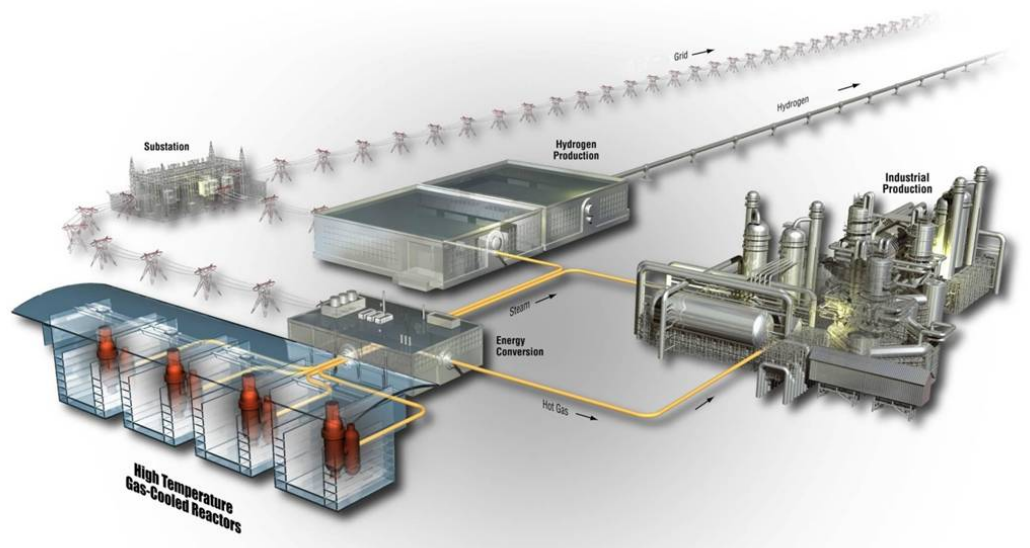

TII Idaho National Laboratory

INL is a U.S. Department of Energy National Laboratory

operated by Batelle Energy Alliance, LLC 


DISCLAIMER
This information was prepared as an account of work sponsored by an
agency of the U.S. Government. Neither the U.S. Government nor any
agency thereof, nor any of their employees, makes any warranty, expressed
or implied, or assumes any legal liability or responsibility for the accuracy,
completeness, or usefulness, of any information, apparatus, product, or
process disclosed, or represents that its use would not infringe privately
owned rights. References herein to any specific commercial product,
process, or service by trade name, trade mark, manufacturer, or otherwise,
does not necessarily constitute or imply its endorsement, recommendation,
or favoring by the U.S. Government or any agency thereof. The views and
opinions of authors expressed herein do not necessarily state or reflect
those of the U.S. Government or any agency thereof.




\title{
Automated Internal Energy Calibration by OnTheFly for AGR-5/6/7
}

\author{
INL ART Program
}

\author{
Edward L. Reber \\ Dawn M. Scates \\ Ryan G. Fronk
}

May 2021

\begin{abstract}
Idaho National Laboratory Advanced Reactor Technologies Idaho Falls, Idaho 83415
\end{abstract}

http://www.ART.INL.gov

Prepared for the U.S. Department of Energy Office of Nuclear Energy Under DOE Idaho Operations Office Contract DE-AC07-05ID14517 
Page intentionally left blank 


\title{
INL ART Program \\ Automated Internal Energy Calibration by OnTheFly for AGR-5/6/7
}

\author{
INL/EXT-21-62709
}

May 2021

Technical Reviewer: (Confirmation of mathematical accuracy, and correctness of data and appropriateness of assumptions.)

Mitchell Plummer

Date

ART Data Streams Technical Lead

Approved by:

Dawn M. Scates

Date

FPMS Experiment Technical Lead

Michael E. Davenport

Date

ART Irradiation Project Manager

Paul A. Demkowicz

Date

ART Project Manager

Michelle T. Sharp

Date

INL Quality Assurance 
Page intentionally left blank 


\begin{abstract}
The software program, OnTheFly, was developed at Idaho National Laboratory (INL) to keep high-purity germanium (HPGe) detectors energy calibrated during very long experiments. Over time, spectra produced from a HPGe detector will slowly stretch or contract, causing the energy calibration to change. If the energy calibration changes too much, it will cause energy lines to be misidentified. The higher the energy line the more affected they are by this change. OnTheFly tracks and adjusts the slowly changing energy calibrations so the energy lines will not be misidentified.

OnTheFly was used with the Fission Product Monitoring System (FPMS) during the AGR-5/6/7 irradiation experiment performed at INL's Advanced Test Reactor (ATR). Five HPGe detectors were used to monitor the five capsules in AGR-5/6/7. There were also two extra HPGe detectors that were maintained as spares. Before each ATR cycle of the experiment, the HPGe detectors were energy calibrated with a thorium radioactive source. During each ATR cycle, each detector would acquire data for 8 hours and then reset and acquire data for another 8 hours. After each 8 -hour run, the spectra would be saved and analyzed autonomously. The results were then read by OnTheFly and used to produce a new energy calibration for each detector. The new energy calibrations were compared to the current energy calibrations and, if certain criteria were met, the new energy calibration would replace the current energy calibration. The new energy calibration would be used for future spectra. OnTheFly was run at least every couple of days but could be run as much as after each 8-hour run.

OnTheFly kept the spectra energy calibrated during the ATR cycles over the 2 years and 5 months that the AGR-5/6/7 experiment ran.
\end{abstract}


Page intentionally left blank 


\section{CONTENTS}

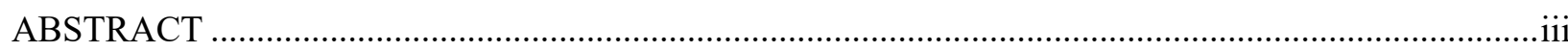

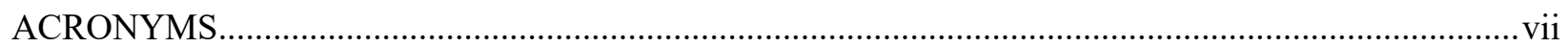

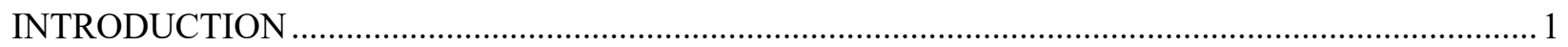

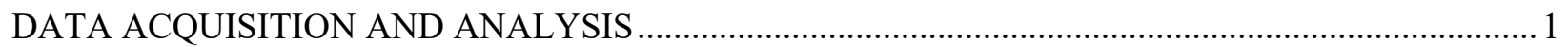

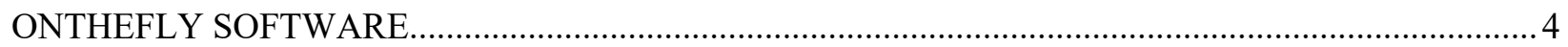

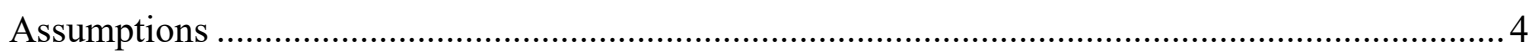

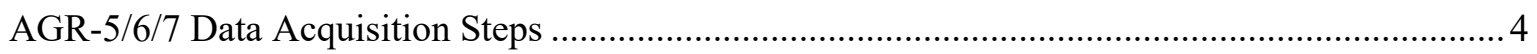

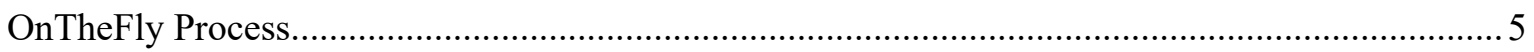

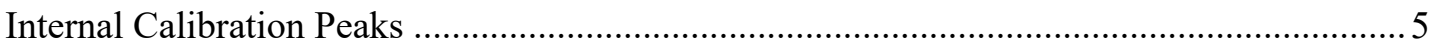

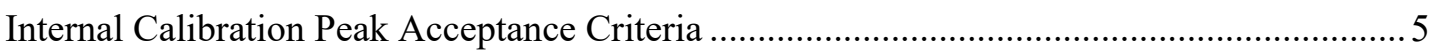

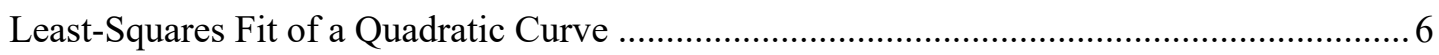

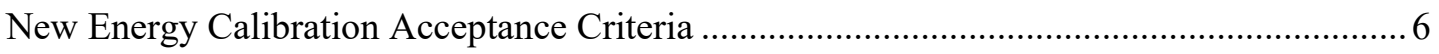

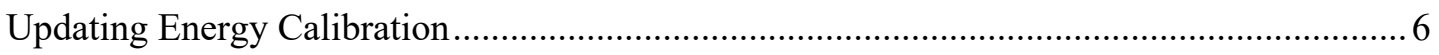

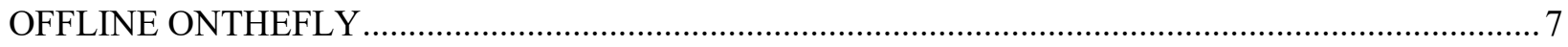

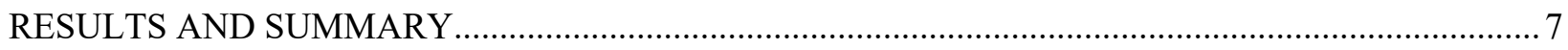

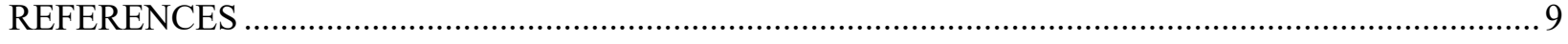

Appendix A Sample of GA1309240300.LIS (real-time analysis) ......................................................... 11

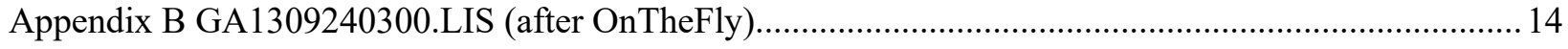

Appendix C OnTheFly Cycle 168A Setup File ................................................................................. 17

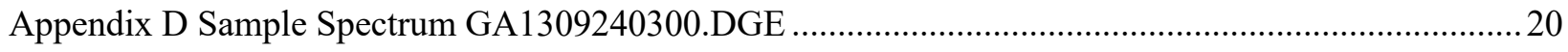

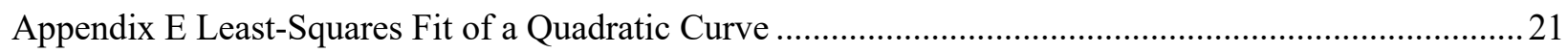

\section{FIGURES}

Figure 1. Kr-88 real-time analysis for AGR3, Cycle 154B, detector GA..............................................

Figure 2. AGR3 experiment, cycle 154B, detector GA, PCGAP analysis of isotope $\mathrm{Kr}-88$ after internal energy calibration is used 8

\section{TABLES}

Table 1. Program Default Values for Peak Acceptance - These default values are used if they are not addressed in the setup file.

Table 2. Checking Energy Calibration Change - These values are used to determine if the new energy calibration has changed only slightly from the previous energy calibration or drastically. 
Table 3. Difference Between Online and Offline Modes - This table highlights the differences between the two modes. 


\section{ACRONYMS}

AGR Advanced Gas Reactor

ATR Advanced Test Reactor

CPS counts per second

DGE Spectrum files in PCGAP have a file extension of '.DGE'

DOE Department of Energy

FPMS Fission Product Monitoring System

GA The 14 HPGe detectors used for the AGR3/4 experiment identified as GA, GB, ... GM, GN

HPGe high-purity germanium

INL Idaho National Laboratory

LIS PCGAP spectrum analysis output

$\mathrm{NaI} \quad$ sodium iodide

PCGAP Personal Computer Gamma Analysis Package

Peak Energy Line 
Page intentionally left blank 


\section{Automated Internal Energy Calibration by OnTheFly for AGR-5/6/7}

\section{INTRODUCTION}

In 2006, the US Department of Energy (DOE) embarked on a series of tests of coated-particle reactor fuel for the Advanced Gas Reactor (AGR) [1]. Part of this fuel development program was a series of seven fuel irradiation tests performed at Idaho National Laboratory's (INL's) Advanced Test Reactor (ATR). Each of the fuel test experiments incorporated multi-capsule fuel test train inserted into an irradiation position in the ATR. The final AGR test combined the last three tests (AGR-5/6/7) into one test train. An important aspect of the fuel performance in these irradiation experiments is quantification of the fission gas release duration the irradiation. The effluent gas from each of the five capsules was independently monitored in near real time and the activity of various fission gas nuclides determined and reported. To meet this important test objective (and provide two spares), a set of seven heavily-shielded high-purity germanium (HPGe) gamma-ray spectrometers and sodium iodide (NaI) scintillation detectorbased total radiation detectors were used during the AGR-5/6/7 experiment. The collection of the radiation measurement systems (including the electronics and data acquisition software) is referred to as the Fission Product Monitoring System (FPMS).

Over the entire AGR series of tests, many ATR cycles lasted over 60 days, and some were over 99 days. This meant it could be more than 2 to 3 months between calibrations of the HPGe detectors. The AGR-5/6/7 experiment ran from February 2018 to July 2020 and even had a cycle last 4 months. Calibrations are affected over time by changes in count rate and room temperature [2]. The higher the energy line in the spectrum the larger the shift. One of the isotopes of interest was ${ }^{88} \mathrm{Kr}$ with an energy line of $2,392 \mathrm{keV}$. This energy line was usually the indicator that energy calibration had shifted too far. This peak was the first to be misidentified. For the experiments AGR-1, AGR-2, and AGR-3/4, a pulser was used to track the variation in the energy calibration [3]. This method was found to be inadequate and reanalysis of many spectra was necessary.

It was determined that energy calibrating the spectra during the ATR cycles was needed. An energy calibration can be calculated using known energy lines in a spectrum. This 'internal' energy calibration was desirable [2] because it allow the spectra to be calibrated without interrupting the measurements. The new energy calibrations were used for the next 8-hour measurement. This process was automated by the development of the computer program, OnTheFly.

\section{DATA ACQUISITION AND ANALYSIS}

As K. Debertin and R.G. Helmer explain in their book [2], for typical experiments using an HPGe detector, an energy calibration spectrum is taken before the experiment begins and the resulting calibration is applied to the spectra taken during the experiment. The energy calibration may change with time, count rate, and room temperature. During the AGR cycles all of these were a factor. The cycles can last over 3 months, the count rates increased, and the room's temperature was not regulated. Additionally, the higher in the energy spectrum, the more shift in HPGe detector energy calibrations. In all the AGR experiments, the detectors looked at an energy range up to 3,000 $\mathrm{keV}$. So, it was essential to use an internal calibration method to keep the energy calibration for each detector accurate throughout each cycle.

The first internal calibration method used during AGR-1, AGR-2, and AGR-3/4 was the pulser method. The pulser method enlisted two pulsers. The low pulser was set in the lower region of the spectrum, about channel 720, and the higher pulser was set to about channel 7200 . The energy equivalents for the pulsers were about $261 \mathrm{keV}$ and $2,614 \mathrm{keV}$. The pulser electronics shift the pulsers to above the 
energy range of interest in the spectrum. The position of the pulser peaks during each run were used to update the values of the energy calibration parameters $[3,4]$.

The large amount of data produced during the AGR experiments require automated analysis. During the AGR experiments there were up to twenty-one HPGe detectors collecting isotopic data and, at the same time, an equal number of NaI detectors were collecting gross gamma count rates. Each of the HPGe detector's spectrum was saved every hour. Every 8 hours the spectrum was reset. This produced 24 spectra per detector per day. The AGR-2 and AGR-3/4 experiments ran concurrently for almost two years. During that time a total of 504 spectra per day were produced. Each spectrum had 20 isotopes of interest, with some having multiple energy lines per isotope, needing to be analyzed. It would be a huge waste of resources for a spectroscopist to analyze each individual spectrum. So, the analysis was automated using Personal Computer Gamma Analysis Package (PCGAP) [4]. Although PCGAP is a suite of computer programs, in this paper PCGAP will be used when referring to any of the suite. PCGAP analysis produces a LIS file which contains both the analysis of individual energy lines and the resulting calculated activity of each isotope of interest.

A sample of an LIS file from AGR-3/4 detector GA taken on September 23, 2013 at 03:55 (GA1309240300.LIS) is shown in Appendix A. Three analysis libraries are used with PCGAP: nuclide, interference, and required. The nuclide library tells PCGAP which isotopes and their energy lines to analyze and reports the amount of activity measured. An energy line is commonly referred to as a peak. The interference library lists any isotope with a peak from the nuclide library that interferes with another isotope's peak. The required library is a list of peaks. These peaks, in general, correspond to the isotopes in the nuclide library. The required library forces PCGAP to fit a peak at the location of the peak listed in the library. Each LIS file is divided into three sections: header, peaks fit, and isotopic summary. The peaks fit section shows all the peaks that were fit, including the peaks found by PCGAP's algorithms and the required peaks from the required library. When a peak is fit, it can also be identified or tagged if the peak's energy corresponds to an isotope listed in the nuclide library. The analysis of the spectrum, shown in Appendix A, misidentifies the $2392.14 \mathrm{keV}$ peak of $\mathrm{Kr}-88$. The energy calibration is far enough off $(>1 \mathrm{keV})$ that PCGAP thinks the peak is located at channel 6587.47 (shown in red), but it actually is at 6590.59 (shown in green). Since the $2392.14 \mathrm{keV}$ peak is the primary peak of $\mathrm{Kr}-88$, the misidentification results in an incorrect activity calculation shown in the isotope summary of $\mathrm{Kr}-88$. The misidentified peak is also shown in red in the summary section.

To monitor the automated PCGAP analysis, data for each isotope was extracted from the LIS files, concatenated, and plotted using OriginPro. The data extracted for each isotope includes its activity and its primary peak's centroid channel, primary peak's centroid energy, calculated by the detector's slot file energy calibration, and the primary peak's gamma rays detected per second, referred to as counts per second (CPS). Figure 1 shows the data plotted from AGR3, Cycle 154B, detector GA's data of the isotope $\mathrm{Kr}-88$. All the plots are over time and combined on one display for an easy visual. The upper left plot of Figure 1 is Kr-88's primary peak's centroid channel, the upper right plot is the calculated centroid energy, and the bottom plot is both Kr-88's activity and the primary peak's CPS. The activities of the isotopes of interest were extracted from the isotope summary of the LIS file. The CPS for the isotope's primary peak was extracted from the peak fit section using a looser criterion than PCGAP. The extraction software looked for the largest peak within $1.5 \mathrm{keV}$ of the isotope's peak. PCGAP tags a peak that is within $1 \mathrm{keV}$ of an isotope's peak. The oval and thick square in Figure 1 highlight the region where PCGAP misidentified the peak $2392.1 \mathrm{keV}$. The black filled circles (activity) drop to near zero because the wrong peak is identified. The thick square in the upper right plot shows were the actual primary peak's centroid drifts to greater than $1 \mathrm{keV}$ from its actual value. 


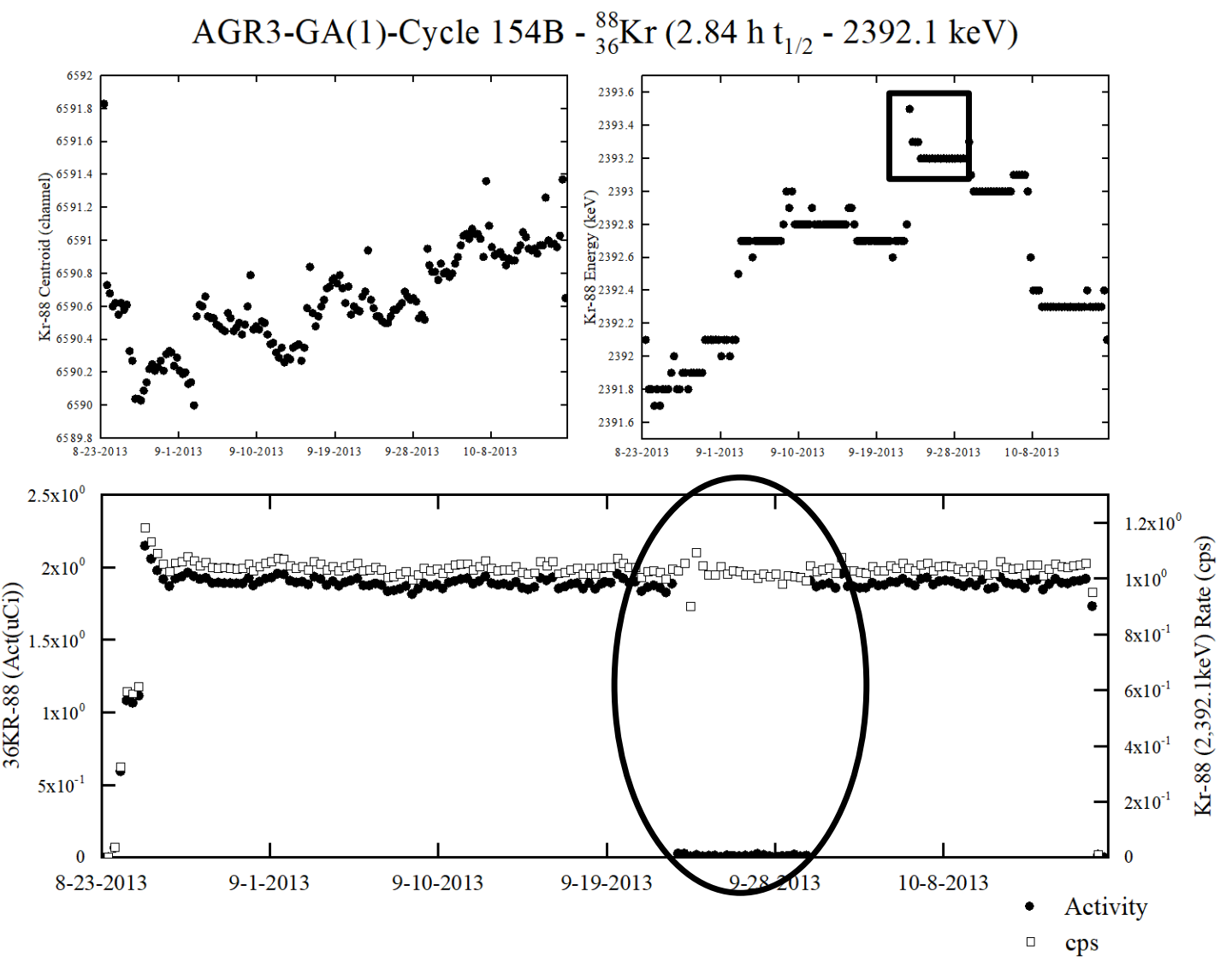

Figure 1. Kr-88 real-time analysis for AGR3, Cycle 154B, detector GA.

PCGAP online analysis of isotope Kr-88 with no internal energy calibration (OnTheFly was not used). The data ploted over time are centroid channel (upper left), centroid energy (upper right) and activity and the $2392 \mathrm{keV}$ peak's gamma rays detectored per second (bottom). The oval highlights the data where the peak $2,392.1 \mathrm{keV}$ is missidentified, resulting in a miscalculation of the $\mathrm{Kr}-88$ activity. The square highlights the corresponding data in the peak-energy tracking plot.

One can tell by a quick glance at Figure 1 something is wrong with the data analysis of Kr- 88 's activity. This type of display was produced for all 20 isotopes of interest for each of the detectors collecting data making it much simpler to identify any problems that might have occurred. The data displayed in Figure 1 was collected while the pulser method was active, but for some reason the analysis did not correct the energy calibration to adjust for the shifting.

Once it was discovered that the primary peak of an isotope was misidentified for a certain amount of time during a cycle, the data was to be reanalyzed offline. A new energy calibration was calculated and used for the spectra during this timeframe. Then the data was reanalyzed to get the correct isotope activities. This was an arduous process leading to the use of the internal energy calibration method instead of the pulser method to keep the calibrations accurate. Once implemented, the pulser electronics were disconnected. Periodically a pulser would fail and using the internal energy calibration method simplified the setup and eliminated the need for repairs. 


\section{ONTHEFLY SOFTWARE}

OnTheFly adjusts a HPGe detector's spectrums energy calibration to keep it accurate during long measurements. OnTheFly is used for repetitive measurements where the spectrum is reset periodically. The AGR measurements meet this criterion. HPGe detectors make 8-hour measurements and then reset. OnTheFly uses 'internal' peaks in the spectrum to energy calibrate the spectrum. The resulting calculated energy calibration is then tested against the current energy calibration and is either accepted or rejected. If accepted, the new calibration is stored and used for the next and future measurements. OnTheFly uses a setup file with many variables that can be adjusted to make the software flexible. Appendix $\mathrm{C}$ shows the OnTheFly setup file from Cycle 168A. As OnTheFly is described below, one detector will be used in the description, but this pertains to all the detectors used in AGR-5/6/7.

\section{Assumptions}

For OnTheFly to keep the energy calibration of a detector's spectrum accurate, the following items must be met:

- Accurate energy calibration at the start of the cycle

Prior to the start of an AGR-5/6/7 cycle, each HPGe detector was energy calibrated using a Th-228 source. The energy calibration was calculated using PCGAP and stored in the detector's slot file. There is a different slot file for each detector on the system. When an 8-hour data acquisition period is complete, the FPMS reads the slot file for a particular detector, inserts the energy calibration into the spectrum, and saves it.

- During the cycle at least three peaks are present

OnTheFly uses 'internal' peaks that are present and expected in the spectrum. An individual peak should be free from interference from other peaks as much as possible. OnTheFly requires at least three peaks chosen across the spectrum. One peak is required in the upper energy range of the spectrum greater than $1,300 \mathrm{keV}$.

- Known internal peak's area will be adequate

Each internal peak's area at the end of a cycle must be large enough to result in an accurate fit. Each individual internal peak's minimum area is defined in the setup file. This minimum is referred to as the peak's area lower limit (Peak_Area_LL) as shown in Appendix C. If an individual internal peak's Peak_Area_LL is not defined the default area lower limit (Default_Area_Lower_Limits) is used.

- Energy calibration gradually shifts

The detectors energy calibration will only shift gradually over time. OnTheFly does not automatically energy calibrate a spectrum with no previous knowledge. The change in the energy calibration from the previous energy calibration to the newly calculated energy calibration must be small.

\section{AGR-5/6/7 Data Acquisition Steps}

The following are the steps in the AGR-5/6/7 data collection including internal energy calibration correction.

1. FPMS collects 8-hour spectra and saves them using the energy calibration from each detector's slot file.

2. Automatic PCGAP analysis produces LIS files.

3. Executing OnTheFly produces new detector slot files (containing new energy calibrations). 
4. New detector slot files replaces slot files on data acquisition computer.

5. Repeat.

\section{OnTheFly Process}

\section{Internal Calibration Peaks}

Once the data is collected, saved, and analyzed, an LIS file is produced and OnTheFly is executed manually. Before OnTheFly is executed for the first time the internal calibration peaks must be selected. Since AGR-5/6/7 was preceded by three other AGR experiments certain peaks were expected. If previous knowledge is not known, one can wait until the first few spectra are produced and then use those spectra to select which peaks to use. The selected peaks for AGR-5/6/7 and their corresponding isotopes are: $80.99 \mathrm{keV}$ (Xe133), $151.18 \mathrm{keV}(\mathrm{Kr} 85 \mathrm{M}), 249.79 \mathrm{keV}$ (Xe135), $258.45 \mathrm{keV}$ (Xe138), $402.64 \mathrm{keV}$ (Kr87), $455.46 \mathrm{keV}$ (Xe137), 462.80 keV (Cs138), 526.56 keV (Xe135M), 586.00 keV (Kr89), 661.66 keV (Cs137), 898.06 keV (Rb88), $1009.78 \mathrm{keV}$ (Cs138), $1141.40 \mathrm{keV}$ (Kr88), $1369.42 \mathrm{keV}$ (Kr88), $1435.86 \mathrm{keV}$ (Cs138), $1529.77 \mathrm{keV}$ (Kr88), $1836.08 \mathrm{keV}$ (Rb88), $2195.80 \mathrm{keV}(\mathrm{Kr} 88), 2218.00 \mathrm{keV}$ (Cs138), 2392.10 keV (Kr88), 2639.59 keV (Cs138). As stated previously, when selecting a peak, it should be free from interference from other peaks as much as possible. Twenty peaks were selected, distributed across the entire spectrum, and consisted of peaks from isotopes with short and long half-lives. It was important to not just have short-lived isotope peaks because when the reactor is shut down, they would disappear quickly. On the other hand, having more peaks distributed across the spectrum results is a better fit. The selected peaks are recorded in the setup file noted by their keV energies. Appendix C shows the sample setup file labeled Calibration_Peaks: that the peaks follow. The line above are the isotopes associated with each peak, this is just for clarity and is ignored by OnTheFly. Any line in the setup file with no colon is ignored by OnTheFly.

\section{Internal Calibration Peak Acceptance Criteria}

One of the first things OnTheFly does is read and process the latest LIS file. OnTheFly builds a tracked-peak list consisting of channel and energy line pairs. OnTheFly scans the peak fits section of the LIS file for each internal calibration peak. If the LIS peak is within a certain $\pm \mathrm{keV}$ range of the internal calibration peak, its centroid channel and the internal calibration peak energy is added to the list. The keV acceptance range is varied linearly with a $\pm 1.0 \mathrm{keV}$ range at channel 150 up to a $\pm 3.5 \mathrm{keV}$ range at channel 6,600. This change is acceptance range is because the spectrum shift increases with increasing energy. If more than one LIS peak falls within the acceptable range of the same internal calibration peak, all but one peak is eliminated. The duplicate peaks are compared against each other, evaluating their fit, area, and area uncertainty. The peak which beats the other peak in two of the three criterium is accepted and the other peak is eliminated.

After the elimination of duplicate peaks, the remaining peaks on the tracked-peak list are evaluated against limits for their values of chi-square, area, and area uncertainty. These limit values may be defined in the setup file. If these values are not defined in the setup file, there are built in default values in OnTheFly, which are shown in Table 1.

Table 1. Program default values for peak acceptance - These default values are used if they are not addressed in the setup file.

\begin{tabular}{|l|l|l|}
\hline \multicolumn{1}{|c|}{ Variable } & \multicolumn{1}{c|}{ Default Limit } & \multicolumn{1}{c|}{ Requirement } \\
\hline Peak Area Lower Limit & 2,000 counts & Minimum \\
\hline $\begin{array}{l}\text { Peak Area Uncertainty } \\
\text { Upper Limit }\end{array}$ & $10 \%$ & Maximum \\
\hline Chi-square Upper Limit & 20 & Maximum \\
\hline
\end{tabular}


Alternative default limits may be defined in the setup file for all three variables. Additionally, individual limit values may be assigned for each internal calibration peak for each detector for the limit variables Peak Area Lower Limit and Chi-square Upper Limit. This makes the program very versatile.

After the internal peaks that do not meet the limits are eliminated, if there are less than three peaks left, calculating a new energy calibration is impossible and no changes are made. Additionally, one of the internal peaks is required to be in the upper energy range of the spectrum greater than $1,300 \mathrm{keV}$. If no peak is greater than $1,300 \mathrm{keV}$ no change is made to the energy calibration.

During AGR-5/6/7 there were occasions when count rates would become large enough to distort certain lower energy peaks $(<260 \mathrm{keV})$. This distortion would cause the peak fits to result in very large chi-square values (100 to 300). Although the chi-square values were large, the resulting peak fits were quite reasonable and acceptable. So these peaks would not be eliminated, a High-Count Rate Chi-square Upper Limit variable was introduced which is defined in the setup file. When a tracked-peak's energy line is less than $260 \mathrm{keV}$ and its area is greater than 2 million, the Chi-square Upper Limit is changed to the High-Count Rate Chi-square Upper Limit (330).

\section{Least-Squares Fit of a Quadratic Curve}

Once the tracked-peak list of channel numbers and their corresponding internal energy lines are built, OnTheFly performs a least-squares fit of a quadratic curve to the list of pairs and produces new energy calibration coefficients. Appendix E shows the routine from OnTheFly to perform the least-squares fit.

\section{New Energy Calibration Acceptance Criteria}

One of the requirements of the new energy calibration is it not being drastically different than the current energy calibration. To determine this, the current and the new calibrations are compared. Comparing the new calculated energy calibration and the existing energy calibration, the values in Table 2 are used to determine if the new calibration is within acceptable limits. Both calibrations are used to calculate an energy at each Check Channel. If any of the resulting values at each Check are more than the Absolute Difference Limit apart, the new energy calibration is rejected. It was found that using a universal limit across the entire spectrum gave dubious results. As stated before, the energy calibration of a spectrum shifts more over time the higher one goes in the spectrum.

Table 2. Checking energy calibration change - These values are used to determine if the new energy calibration has changed only slightly from the previous energy calibration or drastically.

\begin{tabular}{|l|l|l|l|}
\hline \multicolumn{1}{|c|}{ Check } & \multicolumn{1}{|c|}{1} & \multicolumn{1}{c|}{2} & \multicolumn{1}{c|}{3} \\
\hline Check Channel & 150 & 3,000 & 6,580 \\
\hline $\begin{array}{l}\text { Absolute } \\
\text { Difference Limit }\end{array}$ & $1.0 \mathrm{keV}$ & $1.31 \mathrm{keV}$ & $2.1 \mathrm{keV}$ \\
\hline
\end{tabular}

\section{Updating Energy Calibration}

OnTheFly was written to not interfere with the normal operation of FPMS and the data collection of AGR-5/6/7. Additionally, to preserve the original data, no spectrum is overwritten. Therefore, to modify the energy calibration of a spectrum with the newly calculated energy calibration, the detector's slot files are used. Once the new energy calibration is tested and accepted, a slot file is produced for the detector containing the new energy calibration. This slot file is then copied to where these files are kept. When the next 8-hour spectrum has been collected, the FPMS reads the detector's slot file containing the new energy calibration and saves the spectrum with the new energy calibration. The spectrum is automatically analyzed and a LIS file is produced. OnTheFly is executed and the entire process starts over again. 


\section{OFFLINE ONTHEFLY}

OnTheFly has two modes, online and offline. The online mode is described above. The offline mode simulates the online mode and is meant to be used on data that was previously collected. This allows previous AGR experiments to be reanalyzed if drifting occurred and isotopes were misidentified. The data shown in Figure 1 is from AGR-3. When OnTheFly is executed on a regular basis during an experiment the adjustments to the energy calibration of each detector should prevent any misidentification of peaks.

Table 3 shows several differences between the online and offline modes for OnTheFly. In addition to these differences, after OnTheFly is executed in offline mode a new analysis must be performed on all the new DGE that were produced. The new data is displayed similar to Figure 1. These plots are then examined to see if the misidentification of a peak was corrected. Most likely the new energy calibrations fix the problem, but if not, OnTheFly can be executed again using the new DGE files as the original data files and the new LIS files as the analysis files.

Table 3. Difference between online and offline modes - This table highlights the differences between the two modes.

\begin{tabular}{|l|l|l|}
\hline \multicolumn{1}{|c|}{ Item } & \multicolumn{1}{|c|}{ Online } & \multicolumn{1}{c|}{ Offline } \\
\hline $\begin{array}{l}\text { First read of current } \\
\text { energy calibration }\end{array}$ & From the detector's slot file & $\begin{array}{l}\text { From "First pass" folder } \\
\text { containing detector's slot file, } \\
\text { stores pre-Cycle calibration }\end{array}$ \\
\hline Data files (DGE) & Latest DGE written & Next DGE file in DGE folder \\
\hline Analysis (LIS) & $\begin{array}{l}\text { Performed immediately after } \\
\text { end of each 8-hour data } \\
\text { collection }\end{array}$ & $\begin{array}{l}\text { All performed during actual } \\
\text { cycle, LIS files all stored in a } \\
\text { folder to be read }\end{array}$ \\
\hline Modified DGE files & Not modified, only slot files & $\begin{array}{l}\text { When new energy calibration is } \\
\text { accepted, it is embedded in the } \\
\text { DGE file and written to a special } \\
\text { folder. Original DGE file is not } \\
\text { modified. }\end{array}$ \\
\hline
\end{tabular}

\section{RESULTS AND SUMMARY}

To demonstrate how OnTheFly corrects the misidentification of peaks resulting in incorrect activities for isotopes data from AGR3 Cycle 154B, as shown in Figure 1, was run through OnTheFly in offline mode. The resulting DGE files with new energy calibrations were reanalyzed using PCGAP. The results are shown in Figure 2. The oval and thick square highlight the same regions that were highlighted in Figure 1. As shown in Figure 2, the black filled circles (Activity) are no longer near zero due to peak misidentification. The thick square in the upper right plot shows that now the centroid drifts much less. Note the upper left plot, which shows the centroid channel of the peak, does not change because the centroid channel is not affected by changing the energy calibration. 

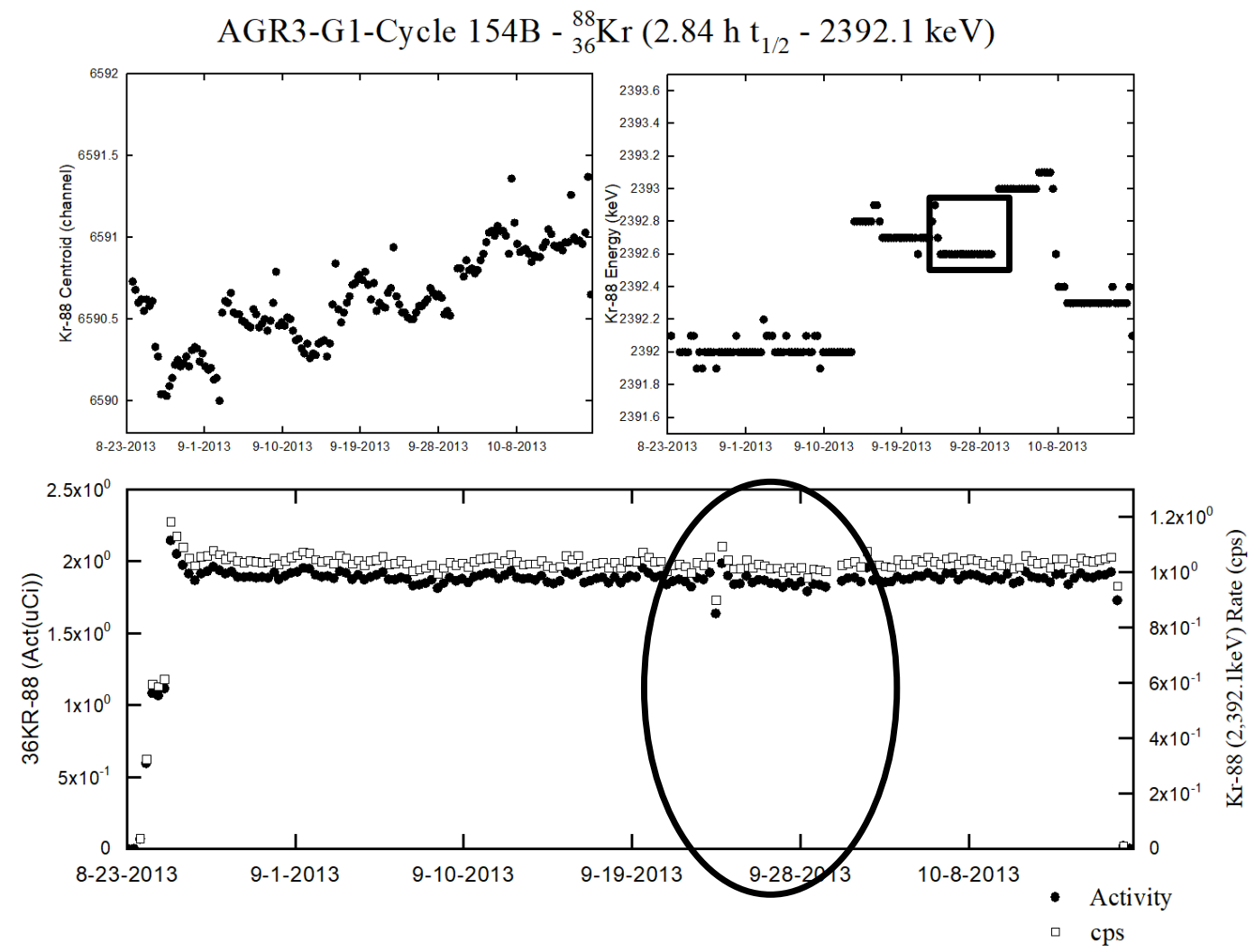

Figure 2. AGR3 experiment, Cycle 154B, detector GA, PCGAP analysis of isotope Kr-88 after internal energy calibration is used (OnTheFly was used to adjust the energy calibration). The oval highlights the data where the energy line 2,392.1 keV is now identified correctly, resulting in the correct calculation of the Kr-88 activity. The square highlights the corresponding data in the peak energy tracking plot.

The software program, OnTheFly, was developed at INL to keep high-purity germanium (HPGe) detectors energy calibrated during long experiments. The program was successfully used with the FPMS during the AGR-5/6/7 irradiation experiment. The OnTheFly program ran at least every couple of days. The OnTheFly program kept the spectra energy calibrated during the ATR cycles over the 2 years and 5 months that the AGR-5/6/7 experiment was irradiated. 


\section{REFERENCES}

1. Advanced Gas Reactor Team, M. A. Feltus, Program Manager, "Technical program plan for the Advanced Gas Reactor fuel development and qualification program," Oak Ridge National Laboratory, Oak Ridge, TN, Tech. Rep. ORNL/TM-2002/262, April 2003.

2. Debertin, K., R.G. Helmer (1988). "Gamma- and X-ray Spectrometry with Semiconductor Detectors,” pp. 194-202, Elsevier Science, 1988.

3. Hartwell, J.K., E.W. Killian (1986). "On-line gamma-ray data acquisition at the power burst facility," Nuclear Instruments and Methods in Physics Research Section A: Accelerators, Spectrometers, Detectors and Associated Equipment, vol. 242, no. 3, pp. 487-492. https://doi.org/10.1016/01689002(86)90452-3.

4. Killian, E.W., J.K. Hartwell (2000). "PCGAP: Users Guide and Algorithm Description," INEEL/EXT-2000-00908. https://digital.library.unt.edu/ark:/67531/metadc884094/. 
Page intentionally left blank 


\section{Appendix A Sample of GA1309240300.LIS (real-time analysis)}

LIS file header:

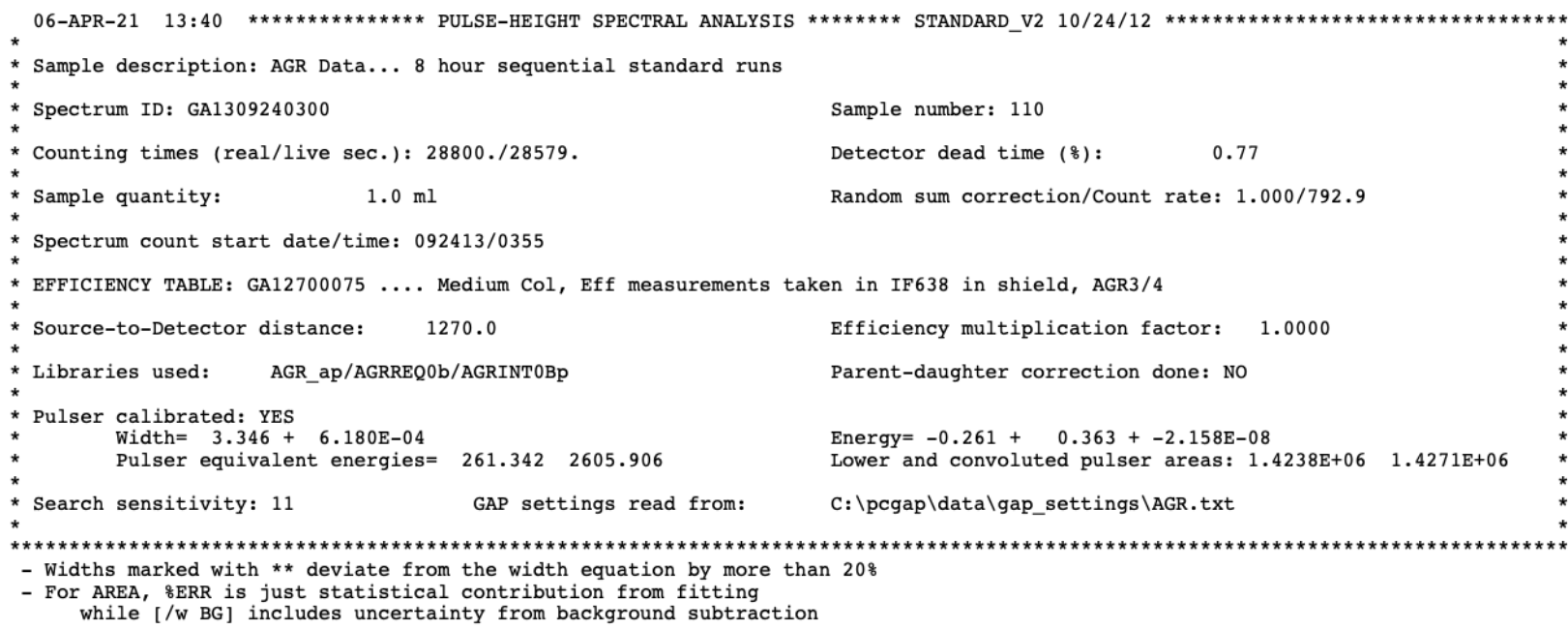

LIS peaks fit:

\begin{tabular}{|c|c|c|c|c|c|c|c|c|c|c|c|c|}
\hline CENTROID & WIDTH & ENERGY & AREA & \&ERR & {$\left[\begin{array}{ll}/ \mathrm{w} & \mathrm{BG}\end{array}\right]$} & $\mathrm{CHI}$ & EFFICIENCY & & PEAK CPS & COR CPS & COR GAM/SEC & \\
\hline \multirow[t]{2}{*}{226.03} & 3.5 & 81.859 & 8476. & 3.51 & {$[3.51]$} & 1.2 & $1.983 \mathrm{E}-04$ & & $2.97 \mathrm{E}-01$ & $2.98 \mathrm{E}-01$ & $1.50 \mathrm{E}+03$ & \\
\hline & & & & & 54 & $\begin{array}{c}\text { TAG } \\
\mathrm{XE} 133\end{array}$ & FIT & $\begin{array}{l}\text { FLAG } \\
2\end{array}$ & $\begin{array}{l}\mathrm{BR}(\mathrm{g}) \\
38.00\end{array}$ & $\begin{array}{l}\mathrm{T}(1 / 2) \mathrm{HR} \\
1.10 \mathrm{E}+13\end{array}$ & $\begin{array}{c}\text { DECAY CORR. } \\
1.000 \mathrm{E}+00\end{array}$ & $\begin{array}{r}\text { INTENSITY CODE } \\
1\end{array}$ \\
\hline \multirow[t]{2}{*}{426.30} & 3.4 & 154.617 & 70046 & 1.73 & {$[1.73]$} & 3.4 & $2.581 \mathrm{E}-04$ & & $2.45 E+00$ & $2.46 \mathrm{E}+00$ & $9.53 \mathrm{E}+03$ & \\
\hline & & & & & 54 & $\begin{array}{c}\text { TAG } \\
\text { XE } 138\end{array}$ & FIT & $\begin{array}{l}\text { FLAG } \\
2\end{array}$ & $\begin{array}{r}\mathrm{BR}(8) \\
5.95\end{array}$ & $\begin{array}{l}\mathrm{T}(1 / 2) \mathrm{HR} \\
1.10 \mathrm{E}+13\end{array}$ & $\begin{array}{c}\text { DECAY CORR. } \\
1.000 \mathrm{E}+00\end{array}$ & $\begin{array}{r}\text { INTENSITY CODE } \\
2\end{array}$ \\
\hline \multirow[t]{2}{*}{459.56} & 3.5 & 166.700 & 15324 & 2.73 & {$[2.73]$} & 1.4 & $2.526 \mathrm{E}-04$ & & $5.36 \mathrm{E}-01$ & $5.38 \mathrm{E}-01$ & $2.13 \mathrm{E}+03$ & \\
\hline & & & & & 36 & $\begin{array}{c}\text { TAG } \\
\text { KR } 88\end{array}$ & FIT & $\begin{array}{l}\text { FLAG } \\
0\end{array}$ & $\begin{array}{r}\mathrm{BR}(\%) \\
3.10\end{array}$ & $\begin{array}{l}\mathrm{T}(1 / 2) \mathrm{HR} \\
1.10 \mathrm{E}+13\end{array}$ & $\begin{array}{c}\text { DECAY CORR. } \\
1.000 \mathrm{E}+00\end{array}$ & $\begin{array}{r}\text { INTENSITY CODE } \\
2\end{array}$ \\
\hline \multirow[t]{2}{*}{543.24} & 4.1 & 197.101 & 126453 & 3.69 & [3.69] & 10.1 & $2.350 \mathrm{E}-04$ & & $4.42 \mathrm{E}+00$ & $4.44 \mathrm{E}+00$ & $1.89 \mathrm{E}+04$ & \\
\hline & & & & & $\begin{array}{l}36 \\
36\end{array}$ & $\begin{array}{c}\text { TAG } \\
\text { KR } 88 \\
\text { KR } 89\end{array}$ & FIT & $\begin{array}{l}\text { FLAG } \\
2 \\
2\end{array}$ & $\begin{array}{r}\mathrm{BR}(\mathrm{8}) \\
25.99 \\
1.81\end{array}$ & $\begin{array}{l}\mathrm{T}(1 / 2) \mathrm{HR} \\
1.10 \mathrm{E}+13 \\
1.10 \mathrm{E}+13\end{array}$ & $\begin{array}{c}\text { DECAY CORR. } \\
1.000 \mathrm{E}+00 \\
1.000 \mathrm{E}+00\end{array}$ & 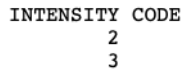 \\
\hline \multirow[t]{2}{*}{670.48} & 3.6 & 243.327 & 34348 . & 1.60 & {$[1.60]$} & 1.6 & $2.072 \mathrm{E}-04$ & & $1.20 \mathrm{E}+00$ & $1.21 \mathrm{E}+00$ & $5.82 \mathrm{E}+03$ & \\
\hline & & & & & 54 & $\begin{array}{c}\text { TAG } \\
\mathrm{XE} 138\end{array}$ & FIT & $\begin{array}{l}\text { FLAG } \\
0\end{array}$ & $\begin{array}{r}\mathrm{BR}\left(\frac{8}{8}\right) \\
3.50\end{array}$ & $\begin{array}{l}\mathrm{T}(1 / 2) \mathrm{HR} \\
1.10 \mathrm{E}+13\end{array}$ & $\begin{array}{c}\text { DECAY CORR. } \\
1.000 \mathrm{E}+00\end{array}$ & $\begin{array}{r}\text { INTENSITY CODE } \\
2\end{array}$ \\
\hline \multirow[t]{2}{*}{713.74} & 3.6 & 259.041 & 288213 & 1.37 & {$[1.37]$} & 6.5 & $1.985 \mathrm{E}-04$ & & $1.01 \mathrm{E}+01$ & $1.01 \mathrm{E}+01$ & $5.10 \mathrm{E}+04$ & \\
\hline & & & & & 54 & $\begin{array}{c}\text { TAG } \\
\mathrm{XE} 138\end{array}$ & FIT & $\begin{array}{l}\text { FLAG } \\
0\end{array}$ & $\begin{array}{l}\mathrm{BR}\left(\frac{8}{8}\right) \\
31.50\end{array}$ & $\begin{array}{l}\mathrm{T}(1 / 2) \mathrm{HR} \\
1.10 \mathrm{E}+13\end{array}$ & $\begin{array}{c}\text { DECAY CORR. } \\
1.000 \mathrm{E}+00\end{array}$ & $\begin{array}{r}\text { INTENSITY CODE } \\
1\end{array}$ \\
\hline \multirow[t]{2}{*}{999.37} & 4.3 & 362.805 & 6356. & 6.85 & {$[6.85]$} & 2.1 & $1.548 \mathrm{E}-04$ & & $2.22 \mathrm{E}-01$ & $2.23 \mathrm{E}-01$ & $1.44 \mathrm{E}+03$ & \\
\hline & & & & & 36 & $\begin{array}{c}\text { TAG } \\
\mathrm{KR} 88\end{array}$ & FIT & $\begin{array}{l}\text { FLAG } \\
2\end{array}$ & $\begin{array}{r}\mathrm{BR}\left(\frac{8}{8}\right) \\
2.25\end{array}$ & $\begin{array}{l}\mathrm{T}(1 / 2) \mathrm{HR} \\
1.10 \mathrm{E}+13\end{array}$ & $\begin{array}{c}\text { DECAY CORR. } \\
1.000 \mathrm{E}+00\end{array}$ & $\begin{array}{r}\text { INTENSITY CODE } \\
2\end{array}$ \\
\hline \multirow[t]{2}{*}{1093.54} & 4.2 & 397.013 & 42093. & 4.70 & {$[4.70]$} & 6.9 & $1.446 \mathrm{E}-04$ & & $1.47 \mathrm{E}+00$ & $1.48 \mathrm{E}+00$ & $1.02 \mathrm{E}+04$ & \\
\hline & & & & & 54 & $\begin{array}{c}\text { TAG } \\
\mathrm{XE} 138\end{array}$ & FIT & $\begin{array}{l}\text { FLAG } \\
2\end{array}$ & $\begin{array}{r}\mathrm{BR}\left(\frac{8}{8}\right) \\
6.30\end{array}$ & $\begin{array}{l}\mathrm{T}(1 / 2) \mathrm{HR} \\
1.10 \mathrm{E}+13\end{array}$ & $\begin{array}{c}\text { DECAY CORR. } \\
1.000 \mathrm{E}+00\end{array}$ & $\begin{array}{r}\text { INTENSITY CODE } \\
2\end{array}$ \\
\hline \multirow[t]{2}{*}{1105.76} & 4.1 & 401.455 & 6219. & 22.65 & [22.65] & 4.8 & $1.434 \mathrm{E}-04$ & & $2.18 \mathrm{E}-01$ & $2.18 \mathrm{E}-01$ & $1.52 \mathrm{E}+03$ & \\
\hline & & & & & 54 & $\begin{array}{l}\text { TAG } \\
\times \mathrm{XE} 138\end{array}$ & FIT & $\begin{array}{l}\text { FLAG } \\
1\end{array}$ & $\begin{array}{r}\mathrm{BR}\left(\frac{8}{6}\right) \\
2.17\end{array}$ & $\begin{array}{l}\mathrm{T}(1 / 2) \mathrm{HR} \\
1.10 \mathrm{E}+13\end{array}$ & $\begin{array}{c}\text { DECAY CORR. } \\
1.000 \mathrm{E}+00\end{array}$ & $\begin{array}{r}\text { INTENSITY CODE } \\
3\end{array}$ \\
\hline
\end{tabular}




\begin{tabular}{|c|c|c|c|c|c|c|c|c|c|c|c|c|}
\hline CENTROID & WIDTH & ENERGY & AREA & \&ERR & {$\left[\begin{array}{lll}/ / w & B G\end{array}\right]$} & $\mathrm{CHI}$ & EFFICIENCY & & EAK CPS & COR CPS & COR GAM/SEC & \\
\hline \multirow[t]{2}{*}{1198.25} & 4.0 & 435.052 & 120761 . & 2.98 & [2.98] & 8.8 & $1.351 \mathrm{E}-04$ & & $4.23 E+00$ & $4.24 \mathrm{E}+00$ & $3.14 \mathrm{E}+04$ & \\
\hline & & & & & 54 & $\begin{array}{c}\text { TAG } \\
\times \mathrm{XE} 138\end{array}$ & FIT & $\begin{array}{l}\text { FLAG } \\
2\end{array}$ & $\begin{array}{l}\mathrm{BR}\left(\frac{8}{5}\right) \\
20.32\end{array}$ & $\begin{array}{l}\mathrm{T}(1 / 2) \mathrm{HR} \\
1.10 \mathrm{E}+13\end{array}$ & $\begin{array}{c}\text { DECAY CORR. } \\
1.000 \mathrm{E}+00\end{array}$ & INTENSITY CODE \\
\hline \multirow[t]{2}{*}{1459.21} & 4.3 & 529.850 & 789. & 56.01 & [56.01] & 1.9 & $1.171 \mathrm{E}-04$ & & $2.76 \mathrm{E}-02$ & $2.77 \mathrm{E}-02$ & $2.36 \mathrm{E}+02$ & \\
\hline & & & & & $\begin{array}{l}53 \\
35 \\
54\end{array}$ & $\begin{array}{ll}\text { TAG } \\
\text { I } & 133 \\
\text { BR } & 83 \\
\text { XE } & 138\end{array}$ & FIT & $\begin{array}{l}\text { FLAG } \\
1 \\
1 \\
1\end{array}$ & $\begin{array}{r}\mathrm{BR}\left(\frac{8}{5}\right) \\
86.31 \\
1.30 \\
0.25\end{array}$ & $\begin{array}{l}\mathrm{T}(1 / 2) \mathrm{HR} \\
1.10 \mathrm{E}+13 \\
1.10 \mathrm{E}+13 \\
1.10 \mathrm{E}+13\end{array}$ & $\begin{array}{c}\text { DECAY CORR. } \\
1.000 \mathrm{E}+00 \\
1.000 \mathrm{E}+00 \\
1.000 \mathrm{E}+00\end{array}$ & $\begin{array}{r}\text { INTENSITY CODE } \\
1 \\
1 \\
4\end{array}$ \\
\hline \multirow[t]{2}{*}{1823.03} & 4.4 & 662.004 & 4148 . & 4.85 & [4.85] & 1.2 & $1.008 \mathrm{E}-04$ & & $1.45 \mathrm{E}-01$ & $1.45 \mathrm{E}-01$ & $1.44 \mathrm{E}+03$ & \\
\hline & & & & & 55 & $\begin{array}{c}\text { TAG } \\
\text { CS } 137\end{array}$ & FIT & $\begin{array}{l}\text { FLAG } \\
2\end{array}$ & $\begin{array}{l}\mathrm{BR}\left(\frac{8}{5}\right) \\
85.20\end{array}$ & $\begin{array}{l}\mathrm{T}(1 / 2) \mathrm{HR} \\
1.10 \mathrm{E}+13\end{array}$ & $\begin{array}{c}\text { DECAY CORR. } \\
1.000 \mathrm{E}+00\end{array}$ & $\begin{array}{r}\text { INTENSITY CODE } \\
1\end{array}$ \\
\hline \multirow[t]{2}{*}{2300.44} & 5.5 & 835.413 & 24750 . & 1.45 & [1.45] & 1.4 & $8.731 \mathrm{E}-05$ & & $8.66 \mathrm{E}-01$ & $8.68 \mathrm{E}-01$ & $9.94 \mathrm{E}+03$ & \\
\hline & & & & & $\begin{array}{l}36 \\
36\end{array}$ & $\begin{array}{c}\text { TAG } \\
\text { KR } 88 \\
\text { KR } 89\end{array}$ & FIT & $\begin{array}{l}\text { FLAG } \\
2 \\
2\end{array}$ & $\begin{array}{r}\mathrm{BR}\left(\frac{8}{8}\right) \\
12.98 \\
1.10\end{array}$ & $\begin{array}{l}\mathrm{T}(1 / 2) \mathrm{HR} \\
1.10 \mathrm{E}+13 \\
1.10 \mathrm{E}+13\end{array}$ & $\begin{array}{c}\text { DECAY CORR. } \\
1.000 \mathrm{E}+00 \\
1.000 \mathrm{E}+00\end{array}$ & $\begin{array}{r}\text { INTENSITY CODE } \\
2 \\
3\end{array}$ \\
\hline \multirow[t]{2}{*}{2715.73} & 5.3 & 986.251 & 2040 . & 7.24 & [ 7.24$]$ & 1.0 & $7.932 \mathrm{E}-05$ & & $7.14 \mathrm{E}-02$ & $7.15 \mathrm{E}-02$ & $9.02 \mathrm{E}+02$ & \\
\hline & & & & & 36 & $\begin{array}{c}\text { TAG } \\
\text { KR } 88\end{array}$ & FIT & $\begin{array}{l}\text { FLAG } \\
2\end{array}$ & $\begin{array}{r}\mathrm{BR}(8) \\
1.32\end{array}$ & $\begin{array}{l}\mathrm{T}(1 / 2) \mathrm{HR} \\
1.10 \mathrm{E}+13\end{array}$ & $\begin{array}{c}\text { DECAY CORR. } \\
1.000 \mathrm{E}+00\end{array}$ & INTENSITY CODE \\
\hline \multirow[t]{2}{*}{3069.23} & 5.2 & 1114.638 & 4732 . & 3.02 & [3.02] & 1.0 & $7.400 \mathrm{E}-05$ & & $1.66 \mathrm{E}-01$ & $1.66 \mathrm{E}-01$ & $2.24 \mathrm{E}+03$ & \\
\hline & & & & & 54 & $\begin{array}{c}\text { TAG } \\
\times \mathrm{XE} 138\end{array}$ & FIT & $\begin{array}{l}\text { FLAG } \\
2\end{array}$ & $\begin{array}{r}\mathrm{BR}\left(\frac{8}{8}\right) \\
1.47\end{array}$ & $\begin{array}{l}\mathrm{T}(1 / 2) \mathrm{HR} \\
1.10 \mathrm{E}+13\end{array}$ & $\begin{array}{l}\text { DECAY CORR. } \\
1.000 \mathrm{E}+00\end{array}$ & INTENSITY CODE \\
\hline \multirow[t]{2}{*}{3144.22} & 5.6 & 1141.872 & 3494 . & 4.73 & [4.73] & 1.1 & $7.299 \mathrm{E}-05$ & & $1.22 \mathrm{E}-01$ & $1.22 \mathrm{E}-01$ & $1.68 \mathrm{E}+03$ & \\
\hline & & & & & $\begin{array}{r}36 \\
0\end{array}$ & $\begin{array}{l}\text { TAG } \\
\text { KR } 88 \\
\text { SUM_KR }\end{array}$ & 89 & $\begin{array}{l}\text { FLAG } \\
2 \\
2\end{array}$ & $\begin{array}{r}\mathrm{BR}\left(\frac{8}{8}\right) \\
1.28 \\
4.18\end{array}$ & $\begin{array}{l}\mathrm{T}(1 / 2) \mathrm{HR} \\
1.10 \mathrm{E}+13 \\
1.10 \mathrm{E}+13\end{array}$ & $\begin{array}{c}\text { DECAY CORR. } \\
1.000 \mathrm{E}+00 \\
1.000 \mathrm{E}+00\end{array}$ & $\begin{array}{r}\text { INTENSITY CODE } \\
2 \\
20\end{array}$ \\
\hline \multirow[t]{2}{*}{4182.62} & 6.2 & 1518.976 & 2178 . & 7.22 & [ 7.22$]$ & 1.2 & $6.166 \mathrm{E}-05$ & & $7.62 \mathrm{E}-02$ & $7.63 \mathrm{E}-02$ & $1.24 \mathrm{E}+03$ & \\
\hline & & & & & 36 & $\begin{array}{c}\text { TAG } \\
\mathrm{KR} 88\end{array}$ & FIT & $\begin{array}{l}\text { FLAG } \\
0\end{array}$ & $\begin{array}{r}\mathrm{BR}\left(\frac{8}{8}\right) \\
2.15\end{array}$ & $\begin{array}{l}\mathrm{T}(1 / 2) \mathrm{HR} \\
1.10 \mathrm{E}+13\end{array}$ & $\begin{array}{c}\text { DECAY CORR. } \\
1.000 \mathrm{E}+00\end{array}$ & INTENSITY CODE \\
\hline \multirow[t]{2}{*}{4215.00} & 6.4 & 1530.736 & 21380 . & .87 & {$[.87]$} & 1.0 & $6.135 \mathrm{E}-05$ & & $7.48 \mathrm{E}-01$ & $7.49 \mathrm{E}-01$ & $1.22 \mathrm{E}+04$ & \\
\hline & & & & & $\begin{array}{l}36 \\
36\end{array}$ & $\begin{array}{c}\text { TAG } \\
\text { KR } 88 \\
\text { KR } 89\end{array}$ & FIT & $\begin{array}{l}\text { FLAG } \\
2 \\
2\end{array}$ & $\begin{array}{r}\mathrm{BR}\left(\frac{8}{8}\right) \\
10.93 \\
3.30\end{array}$ & $\begin{array}{l}\mathrm{T}(1 / 2) \mathrm{HR} \\
1.10 \mathrm{E}+13 \\
1.10 \mathrm{E}+13\end{array}$ & $\begin{array}{c}\text { DECAY CORR. } \\
1.000 \mathrm{E}+00 \\
1.000 \mathrm{E}+00\end{array}$ & $\begin{array}{r}\text { INTENSITY CODE } \\
2 \\
2\end{array}$ \\
\hline \multirow[t]{2}{*}{4871.10} & 6.6 & 1768.977 & 40530 & .68 & {$[.68]$} & 1.2 & $5.563 \mathrm{E}-05$ & & $1.42 \mathrm{E}+00$ & $1.42 \mathrm{E}+00$ & $2.55 E+04$ & \\
\hline & & & & & 54 & $\begin{array}{c}\text { TAG } \\
\times \mathrm{XE} 138\end{array}$ & FIT & $\begin{array}{l}\text { FLAG } \\
2\end{array}$ & $\begin{array}{l}\mathrm{BR}\left(\frac{8}{8}\right) \\
16.73\end{array}$ & $\begin{array}{l}\mathrm{T}(1 / 2) \mathrm{HR} \\
1.10 \mathrm{E}+13\end{array}$ & $\begin{array}{c}\text { DECAY CORR. } \\
1.000 \mathrm{E}+00\end{array}$ & INTENSITY CODE \\
\hline \multirow[t]{2}{*}{5098.72} & 6.4 & 1851.627 & 3063. & 3.66 & [3.66] & 1.0 & $5.379 \mathrm{E}-05$ & & $1.07 \mathrm{E}-01$ & $1.07 \mathrm{E}-01$ & $1.99 \mathrm{E}+03$ & \\
\hline & & & & & $\begin{array}{r}54 \\
0\end{array}$ & $\begin{array}{l}\text { TAG } \\
\text { XE } 138 \\
\text { SUM_KR }\end{array}$ & 89 & $\begin{array}{l}\text { FLAG } \\
0 \\
0\end{array}$ & $\begin{array}{r}\mathrm{BR}\left(\frac{8}{8}\right) \\
1.42 \\
1.35\end{array}$ & $\begin{array}{l}\mathrm{T}(1 / 2) \mathrm{HR} \\
1.10 \mathrm{E}+13 \\
1.10 \mathrm{E}+13\end{array}$ & $\begin{array}{c}\text { DECAY CORR. } \\
1.000 \mathrm{E}+00 \\
1.000 \mathrm{E}+00\end{array}$ & $\begin{array}{r}\text { INTENSITY CODE } \\
3 \\
20\end{array}$ \\
\hline \multirow[t]{2}{*}{5552.41} & 11.8 ** & 2016.357 & 32253. & 6.69 & [6.69] & 9.5 & $5.028 \mathrm{E}-05$ & & $1.13 \mathrm{E}+00$ & $1.13 \mathrm{E}+00$ & $2.25 E+04$ & \\
\hline & & & & & 54 & $\begin{array}{c}\text { TAG } \\
\mathrm{XE} \quad 138\end{array}$ & FIT & $\begin{array}{l}\text { FLAG } \\
2\end{array}$ & $\begin{array}{l}\mathrm{BR}\left(\frac{8}{8}\right) \\
12.25\end{array}$ & $\begin{array}{l}\mathrm{T}(1 / 2) \mathrm{HR} \\
1.10 \mathrm{E}+13\end{array}$ & $\begin{array}{l}\text { DECAY CORR. } \\
1.000 \mathrm{E}+00\end{array}$ & INTENSITY CODE \\
\hline \multirow[t]{2}{*}{5592.08} & 7.1 & 2030.760 & 3963. & 2.74 & [2.74] & 1.1 & $4.998 \mathrm{E}-05$ & & $1.39 \mathrm{E}-01$ & $1.39 \mathrm{E}-01$ & $2.78 \mathrm{E}+03$ & \\
\hline & & & & & 36 & $\begin{array}{c}\text { TAG } \\
\text { KR } 88\end{array}$ & FIT & $\begin{array}{l}\text { FLAG } \\
2\end{array}$ & $\begin{array}{r}\mathrm{BR}\left(\frac{8}{8}\right) \\
4.53\end{array}$ & $\begin{array}{l}\mathrm{T}(1 / 2) \mathrm{HR} \\
1.10 \mathrm{E}+13\end{array}$ & $\begin{array}{c}\text { DECAY CORR. } \\
1.000 \mathrm{E}+00\end{array}$ & INTENSITY CODE \\
\hline \multirow[t]{2}{*}{5607.62} & 7.1 & 2036.400 & 3152 . & 3.25 & [3.25] & 1.1 & $4.987 \mathrm{E}-05$ & & $1.10 \mathrm{E}-01$ & $1.10 \mathrm{E}-01$ & $2.21 \mathrm{E}+03$ & \\
\hline & & & & & 36 & $\begin{array}{c}\text { TAG } \\
\mathrm{KR} 88\end{array}$ & FIT & $\begin{array}{l}\text { FLAG } \\
2\end{array}$ & $\begin{array}{r}\mathrm{BR}(8) \\
3.74\end{array}$ & $\begin{array}{l}\mathrm{T}(1 / 2) \mathrm{HR} \\
1.10 \mathrm{E}+13\end{array}$ & $\begin{array}{c}\text { DECAY CORR. } \\
1.000 \mathrm{E}+00\end{array}$ & $\begin{array}{r}\text { INTENSITY CODE } \\
2\end{array}$ \\
\hline \multirow[t]{2}{*}{5727.70} & 7.1 & 2080.001 & 3297. & 4.80 & {$[4.80]$} & 1.5 & $4.898 \mathrm{E}-05$ & & $1.15 \mathrm{E}-01$ & $1.16 \mathrm{E}-01$ & $2.36 \mathrm{E}+03$ & \\
\hline & & & & & 54 & $\begin{array}{c}\text { TAG } \\
\mathrm{XE} 138\end{array}$ & FIT & $\begin{array}{l}\text { FLAG } \\
0\end{array}$ & $\begin{array}{r}\mathrm{BR}\left(\frac{8}{8}\right) \\
1.44\end{array}$ & $\begin{array}{l}\mathrm{T}(1 / 2) \mathrm{HR} \\
1.10 \mathrm{E}+13\end{array}$ & $\begin{array}{c}\text { DECAY CORR. } \\
1.000 \mathrm{E}+00\end{array}$ & $\begin{array}{r}\text { INTENSITY CODE } \\
3\end{array}$ \\
\hline \multirow[t]{2}{*}{6204.98} & 8.0 & 2253.279 & 4396. & 2.75 & [2.75] & 1.1 & $4.556 \mathrm{E}-05$ & & $1.54 \mathrm{E}-01$ & $1.54 \mathrm{E}-01$ & $3.38 \mathrm{E}+03$ & \\
\hline & & & & & 54 & $\begin{array}{c}\text { TAG } \\
\times \mathrm{XE} 138\end{array}$ & FIT & $\begin{array}{l}\text { FLAG } \\
0\end{array}$ & $\begin{array}{r}\mathrm{BR}\left(\frac{8}{8}\right) \\
2.29\end{array}$ & $\begin{array}{l}\mathrm{T}(1 / 2) \mathrm{HR} \\
1.10 \mathrm{E}+13\end{array}$ & $\begin{array}{l}\text { DECAY CORR. } \\
1.000 \mathrm{E}+00\end{array}$ & INTENSITY CODE \\
\hline \multirow[t]{2}{*}{6587.47} & 7.5 & 2392.140 & 131. & 160. & {$[160]$.} & 1.4 & $4.295 \mathrm{E}-05$ & & $4.59 \mathrm{E}-03$ & $4.60 \mathrm{E}-03$ & $1.07 \mathrm{E}+02$ & \\
\hline & & & & & 36 & $\begin{array}{c}\text { TAG } \\
\mathrm{KR} 88\end{array}$ & FIT & $\begin{array}{l}\text { FLAG } \\
1\end{array}$ & $\begin{array}{l}\mathrm{BR}\left(\frac{8}{8}\right) \\
34.60\end{array}$ & $\begin{array}{l}\mathrm{T}(1 / 2) \mathrm{HR} \\
1.10 \mathrm{E}+13\end{array}$ & $\begin{array}{l}\text { DECAY CORR. } \\
1.000 \mathrm{E}+00\end{array}$ & $\begin{array}{r}\text { INTENSITY } \\
1\end{array}$ \\
\hline \multirow[t]{2}{*}{6590.59} & 7.7 & 2393.273 & 25728 . & .96 & [.96] & 1.4 & $4.293 \mathrm{E}-05$ & & $9.00 \mathrm{E}-01$ & $9.01 \mathrm{E}-01$ & $2.10 \mathrm{E}+04$ & \\
\hline & & & & & 0 & $\begin{array}{l}\text { TAG } \\
\text { SUM_KR }\end{array}$ & 88 & $\begin{array}{l}\text { FLAG } \\
2\end{array}$ & $\begin{array}{r}\mathrm{BR}(8) \\
4.53\end{array}$ & $\begin{array}{l}T(1 / 2) H R \\
1.10 \mathrm{E}+13\end{array}$ & $\begin{array}{c}\text { DECAY CORR. } \\
1.000 \mathrm{E}+00\end{array}$ & $\begin{array}{r}\text { INTENSITY CODE } \\
20\end{array}$ \\
\hline
\end{tabular}


LIS Isotope Summary:

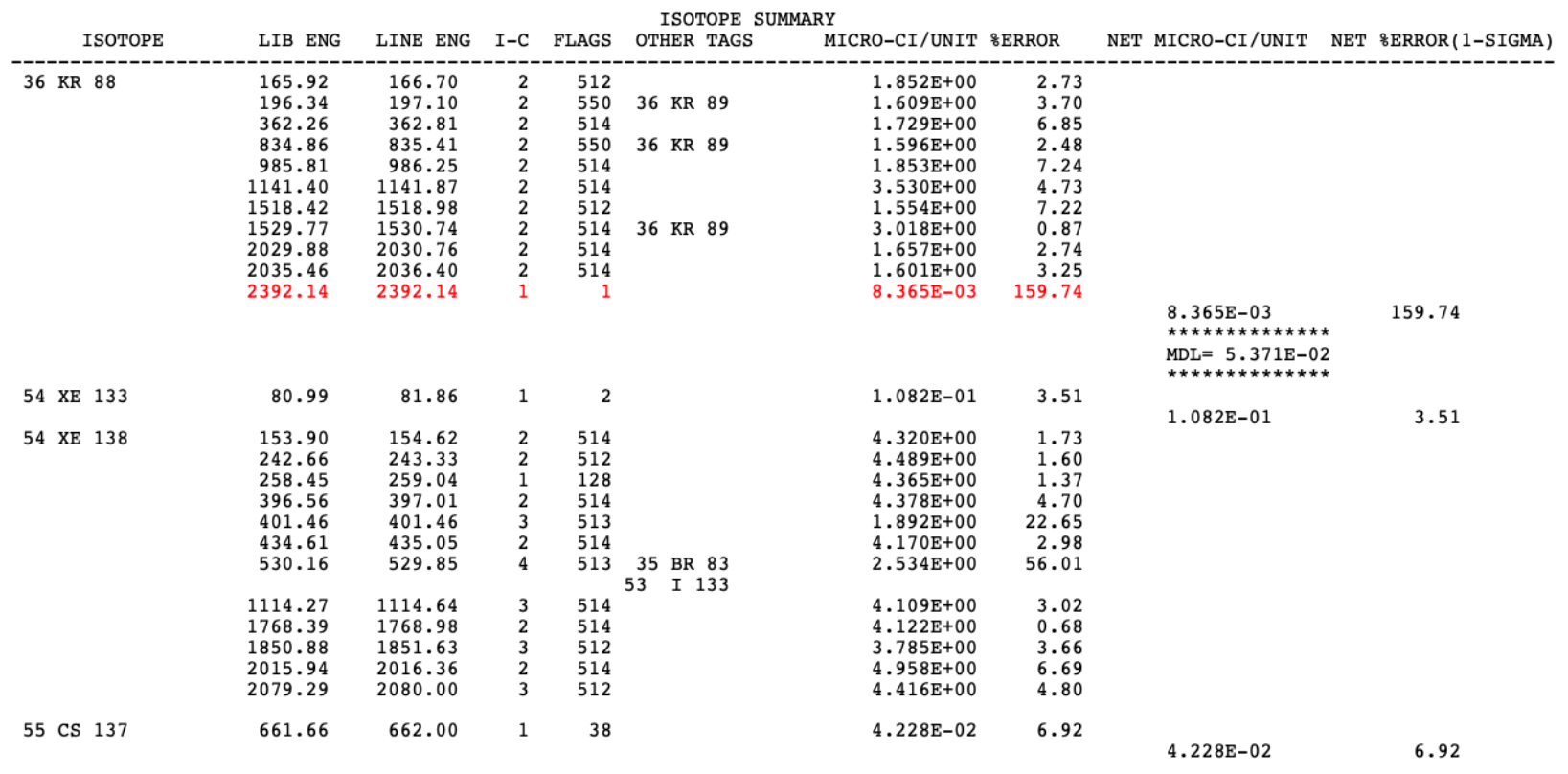




\section{Appendix B GA1309240300.LIS (after OnTheFly)}

LIS file header:

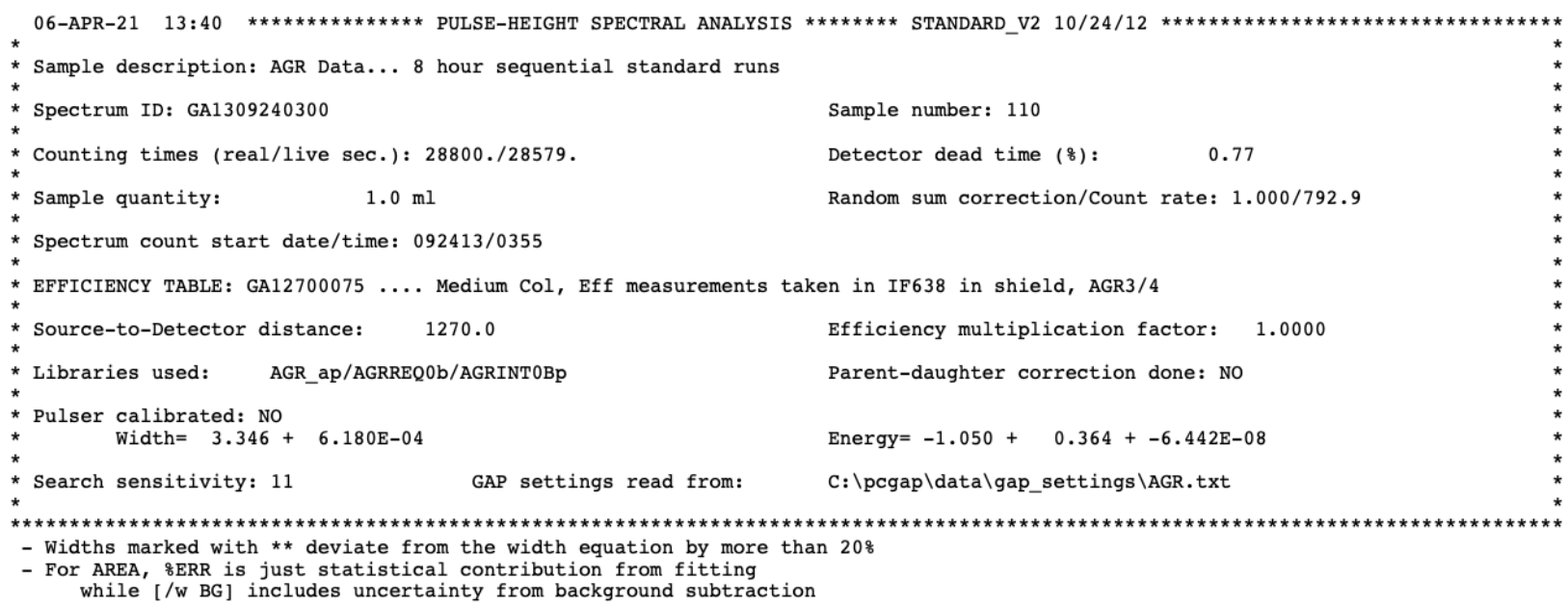

LIS peaks fit:

\begin{tabular}{|c|c|c|c|c|c|c|c|c|c|c|c|c|}
\hline CENTROID & WIDTH & ENERGY & AREA & §ERR & {$\left[\begin{array}{ll}/ \mathrm{w} & \mathrm{BG}\end{array}\right]$} & $\mathrm{CHI}$ & EFFICIENCY & & PEAK CPS & COR CPS & COR GAM/SEC & \\
\hline \multirow[t]{2}{*}{226.03} & 3.5 & 80.734 & 8495 . & 3.52 & [3.52] & 1.2 & $1.948 \mathrm{E}-04$ & & $2.97 \mathrm{E}-01$ & $2.97 \mathrm{E}-01$ & $1.53 \mathrm{E}+03$ & \\
\hline & & & & & $\begin{array}{l}54 \\
53\end{array}$ & $\begin{array}{rr}\text { TAG } \\
\text { XE } & 133 \\
\text { I } & 131\end{array}$ & FIT & $\begin{array}{l}\text { FLAG } \\
2 \\
2\end{array}$ & $\begin{array}{r}\mathrm{BR}(\%) \\
38.00 \\
2.63\end{array}$ & $\begin{array}{l}\mathrm{T}(1 / 2) \mathrm{HR} \\
1.10 \mathrm{E}+13 \\
1.10 \mathrm{E}+13\end{array}$ & $\begin{array}{c}\text { DECAY CORR. } \\
1.000 \mathrm{E}+00 \\
1.000 \mathrm{E}+00\end{array}$ & $\begin{array}{r}\text { INTENSITY CODE } \\
1 \\
3\end{array}$ \\
\hline \multirow[t]{2}{*}{426.30} & 3.4 & 153.541 & 70020 & 1.74 & [ 1.74$]$ & 3.4 & $2.585 \mathrm{E}-04$ & & $2.45 \mathrm{E}+00$ & $2.45 E+00$ & $9.48 \mathrm{E}+03$ & \\
\hline & & & & & 54 & $\begin{array}{c}\text { TAG } \\
\mathrm{XE} 138\end{array}$ & FIT & $\begin{array}{l}\text { FLAG } \\
2\end{array}$ & $\begin{array}{r}\mathrm{BR}\left(\frac{8}{8}\right) \\
5.95\end{array}$ & $\begin{array}{l}\mathrm{T}(1 / 2) \mathrm{HR} \\
1.10 \mathrm{E}+13\end{array}$ & $\begin{array}{l}\text { DECAY CORR. } \\
1.000 \mathrm{E}+00\end{array}$ & $\begin{array}{r}\text { INTENSITY CODE } \\
2\end{array}$ \\
\hline \multirow[t]{2}{*}{459.56} & 3.5 & 165.631 & 15238 & 2.75 & [2.75] & 1.4 & $2.531 \mathrm{E}-04$ & & $5.33 \mathrm{E}-01$ & $5.33 \mathrm{E}-01$ & $2.11 \mathrm{E}+03$ & \\
\hline & & & & & 36 & $\begin{array}{l}\text { TAG } \\
\text { KR } 88\end{array}$ & FIT & $\begin{array}{l}\text { FLAG } \\
0\end{array}$ & $\begin{array}{r}\mathrm{BR}\left(\frac{8}{8}\right) \\
3.10\end{array}$ & $\begin{array}{l}\mathrm{T}(1 / 2) \mathrm{HR} \\
1.10 \mathrm{E}+13\end{array}$ & $\begin{array}{l}\text { DECAY CORR. } \\
1.000 \mathrm{E}+00\end{array}$ & $\underset{2}{\text { INTENSITY CODE }}$ \\
\hline \multirow[t]{2}{*}{543.24} & 4.1 & 196.052 & 126453 . & 3.69 & [3.69] & 10.1 & $2.356 \mathrm{E}-04$ & & $4.42 \mathrm{E}+00$ & $4.42 \mathrm{E}+00$ & $1.88 \mathrm{E}+04$ & \\
\hline & & & & & 36 & $\begin{array}{c}\text { TAG } \\
\mathrm{KR} 88\end{array}$ & FIT & $\begin{array}{l}\text { FLAG } \\
2\end{array}$ & $\begin{array}{l}\mathrm{BR}\left(\frac{8}{8}\right) \\
25.99\end{array}$ & $\begin{array}{l}\mathrm{T}(1 / 2) \mathrm{HR} \\
1.10 \mathrm{E}+13\end{array}$ & $\begin{array}{c}\text { DECAY CORR. } \\
1.000 \mathrm{E}+00\end{array}$ & $\begin{array}{r}\text { INTENSITY CODE } \\
2\end{array}$ \\
\hline \multirow[t]{2}{*}{670.48} & 3.6 & 242.305 & 34348 . & 1.60 & {$[1.60]$} & 1.6 & $2.078 \mathrm{E}-04$ & & $1.20 \mathrm{E}+00$ & $1.20 \mathrm{E}+00$ & $5.78 \mathrm{E}+03$ & \\
\hline & & & & & $\begin{array}{l}54 \\
36\end{array}$ & $\begin{array}{l}\text { TAG } \\
\text { XE } 138 \\
\text { KR } 90\end{array}$ & FIT & $\begin{array}{l}\text { FLAG } \\
0 \\
0\end{array}$ & $\begin{array}{r}\mathrm{BR}(8) \\
3.50 \\
9.23\end{array}$ & $\begin{array}{l}\mathrm{T}(1 / 2) \mathrm{HR} \\
1.10 \mathrm{E}+13 \\
1.10 \mathrm{E}+13\end{array}$ & $\begin{array}{c}\text { DECAY CORR. } \\
1.000 \mathrm{E}+00 \\
1.000 \mathrm{E}+00\end{array}$ & $\begin{array}{r}\text { INTENSITY CODE } \\
2 \\
2\end{array}$ \\
\hline \multirow[t]{2}{*}{713.74} & 3.6 & 258.029 & 288213 & 1.37 & {$[1.37]$} & 6.5 & $1.991 \mathrm{E}-04$ & & $1.01 \mathrm{E}+01$ & $1.01 \mathrm{E}+01$ & $5.07 \mathrm{E}+04$ & \\
\hline & & & & & 54 & $\begin{array}{l}\text { TAG } \\
\mathrm{XE} 138\end{array}$ & FIT & $\begin{array}{l}\text { FLAG } \\
0\end{array}$ & $\begin{array}{l}\mathrm{BR}(\%) \\
31.50\end{array}$ & $\begin{array}{l}\mathrm{T}(1 / 2) \mathrm{HR} \\
1.10 \mathrm{E}+13\end{array}$ & $\begin{array}{l}\text { DECAY CORR. } \\
1.000 \mathrm{E}+00\end{array}$ & $\begin{array}{c}\text { INTENSITY } \\
1\end{array}$ \\
\hline \multirow[t]{2}{*}{999.37} & 4.3 & 361.849 & 6354. & 6.85 & {$[6.85]$} & 2.1 & $1.551 \mathrm{E}-04$ & & $2.22 \mathrm{E}-01$ & $2.22 \mathrm{E}-01$ & $1.43 \mathrm{E}+03$ & \\
\hline & & & & & 36 & $\begin{array}{c}\text { TAG } \\
\text { KR } 88\end{array}$ & FIT & $\begin{array}{l}\text { FLAG } \\
2\end{array}$ & $\begin{array}{r}\mathrm{BR}\left(\frac{8}{8}\right) \\
2.25\end{array}$ & $\begin{array}{l}\mathrm{T}(1 / 2) \mathrm{HR} \\
1.10 \mathrm{E}+13\end{array}$ & $\begin{array}{l}\text { DECAY CORR. } \\
1.000 \mathrm{E}+00\end{array}$ & $\underset{2}{\text { INTENSITY }}$ \\
\hline \multirow[t]{2}{*}{1093.54} & 4.2 & 396.074 & 42092 & 4.70 & {$[4.70]$} & 6.9 & $1.449 \mathrm{E}-04$ & & $1.47 \mathrm{E}+00$ & $1.47 \mathrm{E}+00$ & $1.02 \mathrm{E}+04$ & \\
\hline & & & & & 54 & $\begin{array}{c}\text { TAG } \\
\mathrm{XE} 138\end{array}$ & FIT & $\begin{array}{l}\text { FLAG } \\
2\end{array}$ & $\begin{array}{r}\mathrm{BR}\left(\frac{8}{8}\right) \\
6.30\end{array}$ & $\begin{array}{l}\mathrm{T}(1 / 2) \mathrm{HR} \\
1.10 \mathrm{E}+13\end{array}$ & $\begin{array}{l}\text { DECAY CORR. } \\
1.000 \mathrm{E}+00\end{array}$ & $\begin{array}{r}\text { INTENSITY CODE } \\
2\end{array}$ \\
\hline \multirow[t]{2}{*}{1105.77} & 4.1 & 401.455 & 6225. & 22.67 & {$[22.67]$} & 4.8 & $1.434 \mathrm{E}-04$ & & $2.18 \mathrm{E}-01$ & $2.17 \mathrm{E}-01$ & $1.51 \mathrm{E}+03$ & \\
\hline & & & & & 54 & $\begin{array}{c}\text { TAG } \\
\times E 138\end{array}$ & FIT & $\begin{array}{l}\text { FLAG } \\
1\end{array}$ & $\begin{array}{r}\mathrm{BR}(\%) \\
2.17\end{array}$ & $\begin{array}{l}\mathrm{T}(1 / 2) \mathrm{HR} \\
1.10 \mathrm{E}+13\end{array}$ & $\begin{array}{c}\text { DECAY CORR. } \\
1.000 \mathrm{E}+00\end{array}$ & $\begin{array}{r}\text { INTENSITY CODE } \\
3\end{array}$ \\
\hline
\end{tabular}




\begin{tabular}{|c|c|c|c|c|c|c|c|c|c|c|c|c|}
\hline CENTROID & WIDTH & ENERGY & AREA & \&ิERR & {$\left[\begin{array}{ll}/ \mathrm{w} & \mathrm{BG}\end{array}\right]$} & $\mathrm{CHI}$ & EFFICIENCY & & PEAK CPS & COR CPS & COR $\mathrm{GAM} / \mathrm{SEC}$ & \\
\hline \multirow[t]{2}{*}{1198.25} & 4.0 & 434.131 & 120435 & .59 & {$[.59]$} & 1.8 & $1.353 \mathrm{E}-04$ & & $4.21 \mathrm{E}+00$ & $4.21 \mathrm{E}+00$ & $3.12 \mathrm{E}+04$ & \\
\hline & & & & & $\begin{array}{l}54 \\
36 \\
53\end{array}$ & $\begin{array}{rl}\text { TAG } \\
\mathrm{XE} & 138 \\
\mathrm{KR} & 90 \\
\mathrm{I} & 134\end{array}$ & FIT & $\begin{array}{l}\text { FLAG } \\
2 \\
2 \\
2\end{array}$ & $\begin{array}{r}\text { BR }(8) \\
20.32 \\
1.21 \\
4.20\end{array}$ & $\begin{array}{l}\mathrm{T}(1 / 2) \mathrm{HR} \\
1.10 \mathrm{E}+13 \\
1.10 \mathrm{E}+13 \\
1.10 \mathrm{E}+13\end{array}$ & $\begin{array}{c}\text { DECAY CORR. } \\
1.000 \mathrm{E}+00 \\
1.000 \mathrm{E}+00 \\
1.000 \mathrm{E}+00\end{array}$ & $\begin{array}{rr}\text { INTENSITY } & \text { CODE } \\
2 & \\
2 & \\
2 & \end{array}$ \\
\hline \multirow[t]{2}{*}{1461.64} & 4.2 & 529.850 & 1215. & 22.89 & [22.89] & 1.4 & $1.171 \mathrm{E}-04$ & & $4.25 \mathrm{E}-02$ & $4.25 \mathrm{E}-02$ & $3.63 E+02$ & \\
\hline & & & & & $\begin{array}{l}53 \\
35 \\
54\end{array}$ & $\begin{array}{ll}\text { TAG } \\
\text { I } & 133 \\
\text { BR } & 83 \\
\text { XE } & 138\end{array}$ & FIT & $\begin{array}{l}\text { FLAG } \\
1 \\
1 \\
1\end{array}$ & $\begin{array}{r}\text { BR }(8) \\
86.31 \\
1.30 \\
0.25\end{array}$ & $\begin{array}{l}\mathrm{T}(1 / 2) \mathrm{HR} \\
1.10 \mathrm{E}+13 \\
1.10 \mathrm{E}+13 \\
1.10 \mathrm{E}+13\end{array}$ & $\begin{array}{c}\text { DECAY CORR. } \\
1.000 \mathrm{E}+00 \\
1.000 \mathrm{E}+00 \\
1.000 \mathrm{E}+00\end{array}$ & $\begin{aligned} & \text { INTENSITY } \text { CODE } \\
& 1 \\
& 1 \\
& 4\end{aligned}$ \\
\hline \multirow[t]{2}{*}{1823.03} & 4.4 & 661.170 & 4148 & 4.85 & {$[4.85]$} & 1.2 & $1.008 \mathrm{E}-04$ & & $1.45 \mathrm{E}-01$ & $1.45 \mathrm{E}-01$ & $1.44 \mathrm{E}+03$ & \\
\hline & & & & & $\begin{array}{l}55 \\
36\end{array}$ & $\begin{array}{l}\text { TAG } \\
\text { CS } 137 \\
\text { KR } 89\end{array}$ & FIT & $\begin{array}{l}\text { FLAG } \\
2 \\
2\end{array}$ & $\begin{array}{r}\mathrm{BR}(\%) \\
85.20 \\
0.05\end{array}$ & $\begin{array}{l}\mathrm{T}(1 / 2) \mathrm{HR} \\
1.10 \mathrm{E}+13 \\
1.10 \mathrm{E}+13\end{array}$ & $\begin{array}{c}\text { DECAY CORR. } \\
1.000 \mathrm{E}+00 \\
1.000 \mathrm{E}+00\end{array}$ & $\begin{array}{c}\text { INTENSITY CODE } \\
1 \\
4\end{array}$ \\
\hline \multirow[t]{2}{*}{2300.44} & 5.5 & 834.624 & 24750 & 1.45 & {$[1.45]$} & 1.4 & $8.735 \mathrm{E}-05$ & & $8.66 \mathrm{E}-01$ & $8.66 \mathrm{E}-01$ & $9.91 \mathrm{E}+03$ & \\
\hline & & & & & 36 & $\begin{array}{c}\text { TAG } \\
\text { KR } 88\end{array}$ & FIT & $\begin{array}{l}\text { FLAG } \\
2\end{array}$ & $\begin{array}{l}\mathrm{BR}(8) \\
12.98\end{array}$ & $\begin{array}{l}\mathrm{T}(1 / 2) \mathrm{HR} \\
1.10 \mathrm{E}+13\end{array}$ & $\begin{array}{c}\text { DECAY CORR. } \\
1.000 \mathrm{E}+00\end{array}$ & $\begin{array}{r}\text { INTENSITY CODE } \\
2\end{array}$ \\
\hline \multirow[t]{2}{*}{2715.73} & 5.3 & 985.486 & 2040 & 7.24 & [ 7.24$]$ & 1.0 & $7.935 \mathrm{E}-05$ & & $7.14 \mathrm{E}-02$ & $7.14 \mathrm{E}-02$ & $9.00 \mathrm{E}+02$ & \\
\hline & & & & & 36 & $\begin{array}{c}\text { TAG } \\
\text { KR } 88\end{array}$ & FIT & $\begin{array}{l}\text { FLAG } \\
2\end{array}$ & $\begin{array}{r}\mathrm{BR}\left(\frac{8}{8}\right) \\
1.32\end{array}$ & $\begin{array}{l}\mathrm{T}(1 / 2) \mathrm{HR} \\
1.10 \mathrm{E}+13\end{array}$ & $\begin{array}{c}\text { DECAY CORR. } \\
1.000 \mathrm{E}+00\end{array}$ & $\begin{array}{r}\text { INTENSITY CODE } \\
2\end{array}$ \\
\hline \multirow[t]{2}{*}{3069.23} & 5.2 & 1113.880 & 4732 & 3.02 & {$[3.02]$} & 1.0 & $7.403 \mathrm{E}-05$ & & $1.66 \mathrm{E}-01$ & $1.66 \mathrm{E}-01$ & $2.24 \mathrm{E}+03$ & \\
\hline & & & & & 54 & $\begin{array}{c}\text { TAG } \\
\text { XE } 138\end{array}$ & FIT & $\begin{array}{l}\text { FLAG } \\
2\end{array}$ & $\begin{array}{r}\mathrm{BR}\left(\frac{8}{8}\right) \\
1.47\end{array}$ & $\begin{array}{l}\mathrm{T}(1 / 2) \mathrm{HR} \\
1.10 \mathrm{E}+13\end{array}$ & $\begin{array}{l}\text { DECAY CORR. } \\
1.000 \mathrm{E}+00\end{array}$ & $\begin{array}{r}\text { INTENSITY CODE } \\
3\end{array}$ \\
\hline \multirow[t]{2}{*}{3144.22} & 5.6 & 1141.114 & 3491 . & 4.73 & {$[4.73]$} & 1.1 & $7.302 \mathrm{E}-05$ & & $1.22 \mathrm{E}-01$ & $1.22 \mathrm{E}-01$ & $1.67 \mathrm{E}+03$ & \\
\hline & & & & & $\begin{array}{r}36 \\
0\end{array}$ & $\begin{array}{l}\text { TAG } \\
\text { KR } 88 \\
\text { SUM_KR }\end{array}$ & FIT & $\begin{array}{l}\text { FLAG } \\
2 \\
2\end{array}$ & $\begin{array}{r}\mathrm{BR}(\mathrm{8}) \\
1.28 \\
1.11\end{array}$ & $\begin{array}{l}\mathrm{T}(1 / 2) \mathrm{HR} \\
1.10 \mathrm{E}+13 \\
1.10 \mathrm{E}+13\end{array}$ & $\begin{array}{c}\text { DECAY CORR. } \\
1.000 \mathrm{E}+00 \\
1.000 \mathrm{E}+00\end{array}$ & $\begin{array}{r}\text { INTENSITY CODE } \\
2 \\
20\end{array}$ \\
\hline \multirow[t]{2}{*}{4182.62} & 6.2 & 1518.174 & 2178 & 7.22 & {$[7.22]$} & 1.2 & $6.168 \mathrm{E}-05$ & & $7.62 \mathrm{E}-02$ & $7.62 \mathrm{E}-02$ & $1.24 \mathrm{E}+03$ & \\
\hline & & & & & $\begin{array}{r}36 \\
0\end{array}$ & $\begin{array}{l}\text { TAG } \\
\text { KR } 88 \\
\text { SUM_KR }\end{array}$ & FIT & $\begin{array}{l}\text { FLAG } \\
0 \\
0\end{array}$ & $\begin{array}{r}\mathrm{BR}\left(\frac{8}{8}\right) \\
2.15 \\
7.34\end{array}$ & $\begin{array}{l}\mathrm{T}(1 / 2) \mathrm{HR} \\
1.10 \mathrm{E}+13 \\
1.10 \mathrm{E}+13\end{array}$ & $\begin{array}{c}\text { DECAY CORR. } \\
1.000 \mathrm{E}+00 \\
1.000 \mathrm{E}+00\end{array}$ & $\begin{array}{r}\text { INTENSITY CODE } \\
2 \\
20\end{array}$ \\
\hline \multirow[t]{2}{*}{4215.03} & 6.4 & 1529.941 & 21290 & .87 & {$[.87]$} & 1.0 & $6.137 \mathrm{E}-05$ & & $7.45 \mathrm{E}-01$ & $7.45 \mathrm{E}-01$ & $1.21 \mathrm{E}+04$ & \\
\hline & & & & & $\begin{array}{l}36 \\
36\end{array}$ & $\begin{array}{c}\text { TAG } \\
\text { KR } 88 \\
\text { KR } 89\end{array}$ & FIT & $\begin{array}{l}\text { FLAG } \\
2 \\
2\end{array}$ & $\begin{array}{r}\mathrm{BR}(8) \\
10.93 \\
3.30\end{array}$ & $\begin{array}{l}\mathrm{T}(1 / 2) \mathrm{HR} \\
1.10 \mathrm{E}+13 \\
1.10 \mathrm{E}+13\end{array}$ & $\begin{array}{c}\text { DECAY CORR. } \\
1.000 \mathrm{E}+00 \\
1.000 \mathrm{E}+00\end{array}$ & $\begin{array}{r}\text { INTENSITY CODE } \\
2 \\
2\end{array}$ \\
\hline \multirow[t]{2}{*}{4871.10} & 6.6 & 1768.094 & 40566 & .68 & {$[.68]$} & 1.2 & $5.565 \mathrm{E}-05$ & & $1.42 \mathrm{E}+00$ & $1.42 \mathrm{E}+00$ & $2.55 E+04$ & \\
\hline & & & & & $\begin{array}{r}54 \\
0\end{array}$ & $\begin{array}{l}\text { TAG } \\
\text { XE } 138 \\
\text { SUM_I I }\end{array}$ & 134 & $\begin{array}{l}\text { FLAG } \\
2 \\
2\end{array}$ & $\begin{array}{l}\mathrm{BR}(8) \\
16.73 \\
64.87\end{array}$ & $\begin{array}{l}\mathrm{T}(1 / 2) \mathrm{HR} \\
1.10 \mathrm{E}+13 \\
1.10 \mathrm{E}+13\end{array}$ & $\begin{array}{c}\text { DECAY CORR. } \\
1.000 \mathrm{E}+00 \\
1.000 \mathrm{E}+00\end{array}$ & $\begin{array}{r}\text { INTENSITY CODE } \\
20 \\
20\end{array}$ \\
\hline \multirow[t]{2}{*}{5098.72} & 6.4 & 1850.708 & 3063 . & 3.66 & {$[3.66]$} & 1.0 & $5.381 \mathrm{E}-05$ & & $1.07 \mathrm{E}-01$ & $1.07 \mathrm{E}-01$ & $1.99 \mathrm{E}+03$ & \\
\hline & & & & & 54 & $\begin{array}{c}\text { TAG } \\
\text { XE } 138\end{array}$ & FIT & $\begin{array}{l}\text { FLAG } \\
0\end{array}$ & $\begin{array}{r}\mathrm{BR}\left(\frac{8}{8}\right) \\
1.42\end{array}$ & $\begin{array}{l}\mathrm{T}(1 / 2) \mathrm{HR} \\
1.10 \mathrm{E}+13\end{array}$ & $\begin{array}{c}\text { DECAY CORR. } \\
1.000 \mathrm{E}+00\end{array}$ & $\begin{array}{r}\text { INTENSITY CODE } \\
3\end{array}$ \\
\hline \multirow[t]{2}{*}{5552.41} & $11.8 * *$ & 2015.353 & 32253 & 6.69 & [6.69] & 9.5 & $5.030 \mathrm{E}-05$ & & $1.13 \mathrm{E}+00$ & $1.13 \mathrm{E}+00$ & $2.24 \mathrm{E}+04$ & \\
\hline & & & & & 54 & $\begin{array}{c}\text { TAG } \\
\text { XE } 138\end{array}$ & FIT & $\begin{array}{l}\text { FLAG } \\
2\end{array}$ & $\begin{array}{l}\mathrm{BR}\left(\frac{8}{8}\right) \\
12.25\end{array}$ & $\begin{array}{l}\mathrm{T}(1 / 2) \mathrm{HR} \\
1.10 \mathrm{E}+13\end{array}$ & $\begin{array}{l}\text { DECAY CORR. } \\
1.000 \mathrm{E}+00\end{array}$ & $\begin{array}{r}\text { INTENSITY CODE } \\
2\end{array}$ \\
\hline \multirow[t]{2}{*}{5592.08} & 7.1 & 2029.749 & 3963. & 2.74 & {$[2.74]$} & 1.1 & $5.000 \mathrm{E}-05$ & & $1.39 \mathrm{E}-01$ & $1.39 \mathrm{E}-01$ & $2.77 \mathrm{E}+03$ & \\
\hline & & & & & $\begin{array}{l}36 \\
35\end{array}$ & $\begin{array}{c}\text { TAG } \\
\text { KR } 88 \\
\text { BR } 84\end{array}$ & FIT & $\begin{array}{l}\text { FLAG } \\
2 \\
2\end{array}$ & $\begin{array}{r}\mathrm{BR}\left(\frac{8}{8}\right) \\
4.53 \\
2.05\end{array}$ & $\begin{array}{l}\mathrm{T}(1 / 2) \mathrm{HR} \\
1.10 \mathrm{E}+13 \\
1.10 \mathrm{E}+13\end{array}$ & $\begin{array}{c}\text { DECAY CORR. } \\
1.000 \mathrm{E}+00 \\
1.000 \mathrm{E}+00\end{array}$ & $\begin{array}{r}\text { INTENSITY CODE } \\
2 \\
2\end{array}$ \\
\hline \multirow[t]{2}{*}{5607.62} & 7.1 & 2035.386 & 3152 . & 3.25 & [3.25] & 1.1 & $4.989 \mathrm{E}-05$ & & $1.10 \mathrm{E}-01$ & $1.10 \mathrm{E}-01$ & $2.21 \mathrm{E}+03$ & \\
\hline & & & & & 36 & $\begin{array}{c}\text { TAG } \\
\text { KR } 88\end{array}$ & FIT & $\begin{array}{l}\text { FLAG } \\
2\end{array}$ & $\begin{array}{r}\mathrm{BR}\left(\frac{8}{8}\right) \\
3.74\end{array}$ & $\begin{array}{l}\mathrm{T}(1 / 2) \mathrm{HR} \\
1.10 \mathrm{E}+13\end{array}$ & $\begin{array}{l}\text { DECAY CORR. } \\
1.000 \mathrm{E}+00\end{array}$ & $\begin{array}{r}\text { INTENSITY CODE } \\
2\end{array}$ \\
\hline \multirow[t]{2}{*}{5727.70} & 7.1 & 2078.961 & 3300 . & 4.80 & {$[4.80]$} & 1.5 & $4.900 \mathrm{E}-05$ & & $1.15 \mathrm{E}-01$ & $1.15 \mathrm{E}-01$ & $2.36 \mathrm{E}+03$ & \\
\hline & & & & & 54 & $\begin{array}{c}\text { TAG } \\
\text { XE } 138\end{array}$ & FIT & $\begin{array}{l}\text { FLAG } \\
0\end{array}$ & $\begin{array}{r}\mathrm{BR}\left(\frac{8}{8}\right) \\
1.44\end{array}$ & $\begin{array}{l}\mathrm{T}(1 / 2) \mathrm{HR} \\
1.10 \mathrm{E}+13\end{array}$ & $\begin{array}{c}\text { DECAY CORR. } \\
1.000 \mathrm{E}+00\end{array}$ & $\underset{3}{\text { INTENSITY CODE }}$ \\
\hline \multirow[t]{2}{*}{6204.98} & 8.0 & 2252.124 & 4396. & 2.75 & {$[2.75]$} & 1.1 & $4.558 \mathrm{E}-05$ & & $1.54 \mathrm{E}-01$ & $1.54 \mathrm{E}-01$ & $3.37 \mathrm{E}+03$ & \\
\hline & & & & & 54 & $\begin{array}{c}\text { TAG } \\
\mathrm{XE} 138\end{array}$ & FIT & $\begin{array}{l}\text { FLAG } \\
0\end{array}$ & $\begin{array}{r}\mathrm{BR}(8) \\
2.29\end{array}$ & $\begin{array}{l}\mathrm{T}(1 / 2) \mathrm{HR} \\
1.10 \mathrm{E}+13\end{array}$ & $\begin{array}{c}\text { DECAY CORR. } \\
1.000 \mathrm{E}+00\end{array}$ & $\begin{array}{r}\text { INTENSITY CODE } \\
3\end{array}$ \\
\hline \multirow[t]{2}{*}{6590.59} & 7.7 & 2392.011 & 25728 . & .96 & {$[.96]$} & 1.4 & $4.295 \mathrm{E}-05$ & & $9.00 \mathrm{E}-01$ & $9.00 \mathrm{E}-01$ & $2.10 \mathrm{E}+04$ & \\
\hline & & & & & $\begin{array}{r}36 \\
0\end{array}$ & $\begin{array}{l}\text { TAG } \\
\text { KR } 88 \\
\text { SUM I I }\end{array}$ & 135 & $\begin{array}{l}\text { FLAG } \\
2 \\
2\end{array}$ & $\begin{array}{l}\mathrm{BR}(8) \\
34.60 \\
28.63\end{array}$ & $\begin{array}{l}\mathrm{T}(1 / 2) \mathrm{HR} \\
1.10 \mathrm{E}+13 \\
1.10 \mathrm{E}+13\end{array}$ & $\begin{array}{c}\text { DECAY CORR. } \\
1.000 \mathrm{E}+00 \\
1.000 \mathrm{E}+00\end{array}$ & $\begin{array}{r}\text { INTENSITY CODE } \\
1 \\
20\end{array}$ \\
\hline
\end{tabular}


LIS Isotope Summary:

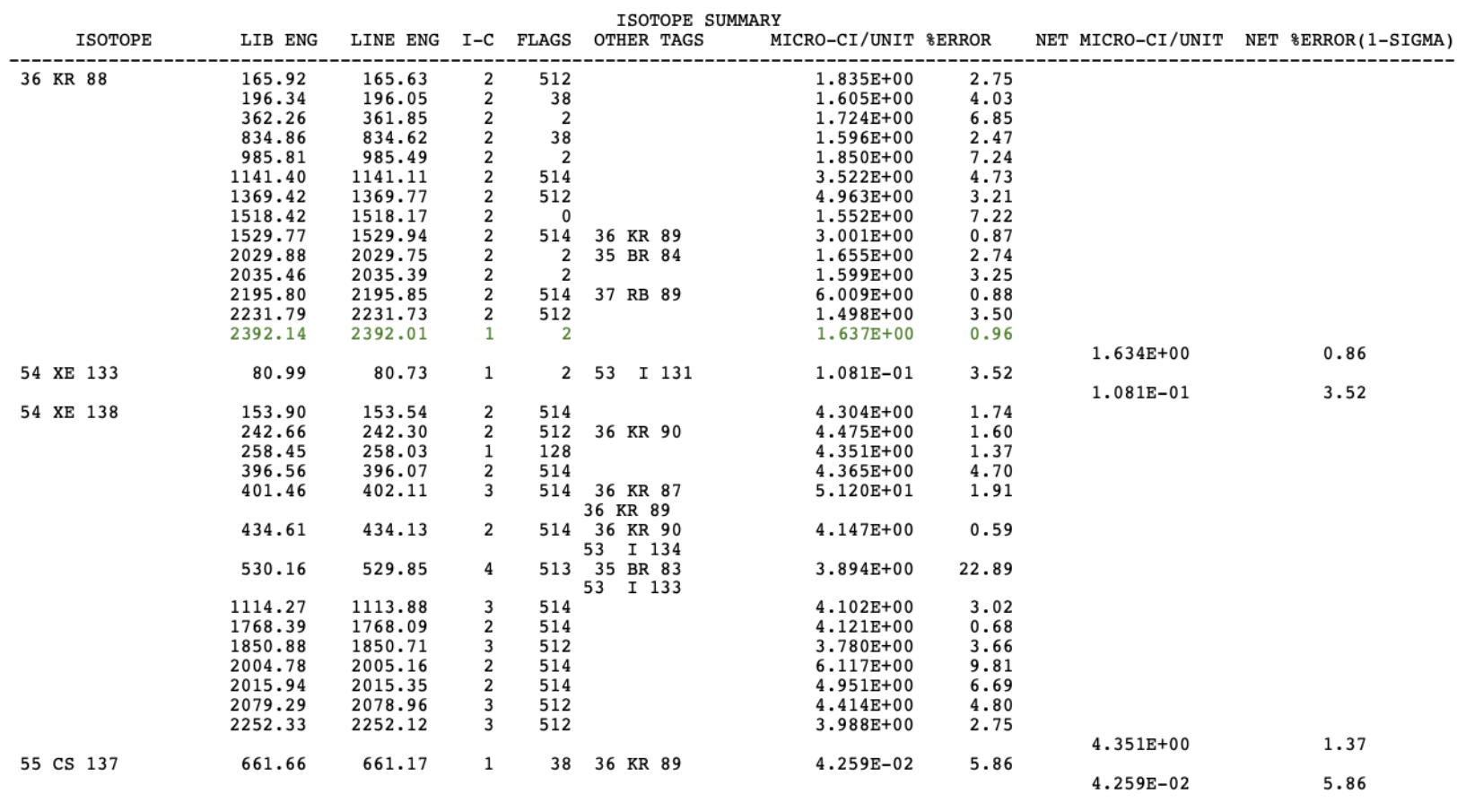




\section{Appendix C OnTheFly Cycle 168A Setup File}

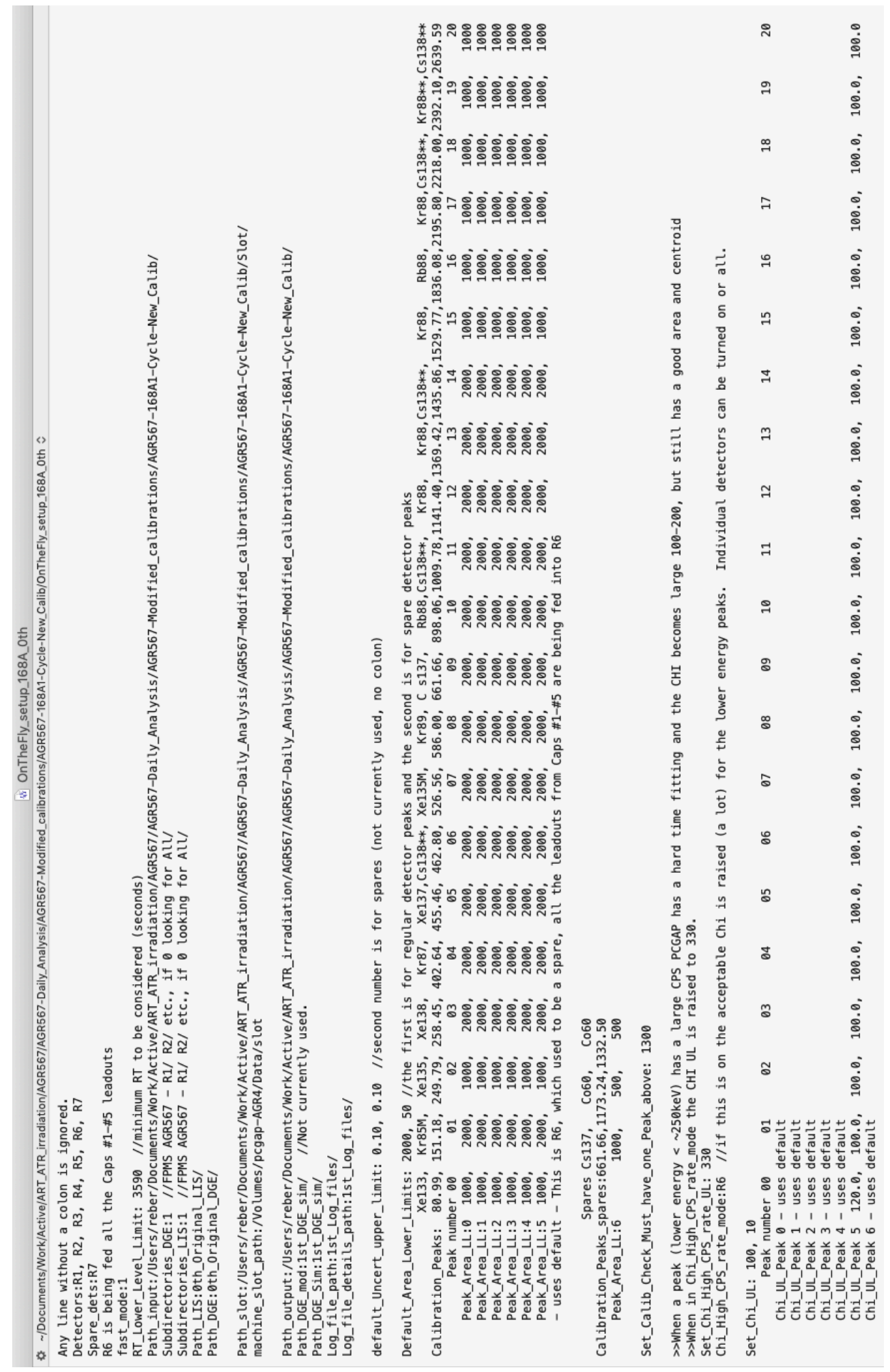


is OnTheFly_setup_168A

\$ /Documents/Work/Active/ART_ATR_irradiation/AGR567/AGR567-Daily_Analysis/AGR567-Modified_calibrations/AGR567-168A1-Cycl

Any line without a colon is ignored.

Detectors:R1, R2, R3, R4, R5, R6, R7

Spare_dets:R7

R6 is being fed all the Caps \#1-\#5 leadouts

fast_mode: 1

RT_Lower_Level_Limit: 3590 //minimum RT to be considered (seconds)

Path_input:/Users/reber/Documents/Work/Active/ART_ATR_irradiation/AGR567/AGR567-Daily_Analysis/AGR

Subdirectories_DGE:1 //FPMS AGR567 - R1/ R2/ etc., if 0 looking for All/

Subdirectories_LIS:1 //FPMS AGR567 - R1/ R2/ etc., if 0 looking for All/

Path_LIS: 0 th_Original_LIS/

Path_DGE:0th_0riginal_DGE/

Path_slot:/Users/reber/Documents/Work/Active/ART_ATR_irradiation/AGR567/AGR567-Daily_Analysis/AGR5 machine_slot_path:/Volumes/pcgap-AGR4/Data/slot

Path_output:/Users/reber/Documents/Work/Active/ART_ATR_irradiation/AGR567/AGR567-Daily_Analysis/AG Path_DGE_mod:1st_DGE_sim/ //Not currently used.

Path_DGE_Sim:1st_DGE_sim/

Log_file_path:1st_Log_files/

Log_file_details_path:1st_Log_files/

default_Uncert_upper_limit: $0.10,0.10 / /$ second number is for spares (not currently used, no colo

Default_Area_Lower_Limits: $2000,50 / /$ the first is for regular detector peaks and the second is fo Xe133, Kr85M, Xe135, Xe138, Kr87, Xe137,Cs138**, Xe135M, Kr89, C s137, Calibration_Peaks: $80.99,151.18,249.79,258.45,402.64,455.46,462.80,526.56,586.00,661.66$, $\begin{array}{llllllllll}\text { Peak number } 00 & 01 & 02 & 03 & 04 & 05 & 06 & 07 & 08 & 09\end{array}$ Peak_Area_LL: $01000,2000,2000,2000,2000,2000,2000, \quad 2000, \quad 2000, \quad 2000$, Peak_Area_LL:1 1000, 2000, 1000, 2000, 2000, 2000, 2000, 2000, 2000, 2000, Peak_Area_LL: 2 1000, 2000, 1000, 2000, 2000, 2000, 2000, 2000, 2000, 2000, Peak_Area_LL:3 1000, 2000, 1000, 2000, 2000, 2000, 2000, 2000, 2000, 2000, Peak_Area_LL: 4 1000, 2000, 1000, 2000, 2000, 2000, 2000, 2000, 2000, 2000, Peak_Area_LL:5 1000, 2000, 1000, 2000, 2000, 2000, 2000, 2000, 2000, 2000, - uses default - This is R6, which used to be a spare, all the leadouts from Caps \#1-\#5 are b

Spares Cs137, Co60, Co60

Calibration_Peaks_spares:661.66,1173.24,1332.50

Peak_Area_LL:6 $6000,500,500$

Set_Calib_Check_Must_have_one_Peak_above: 1300

> When a peak (lower energy $<\sim 250 \mathrm{keV}$ ) has a large CPS PCGAP has a hard time fitting and the CHI $b$ > When in Chi_High_CPS_rate_mode the CHI UL is raised to 330 .

Set_Chi_High_CPS_rate_UL: $3 \overline{3} 0$

Chi_High_CPS_rate_mode:R6 //if this is on the acceptable Chi is raised (a lot) for the lower ener

Set_Chi_UL: 100,10

Peak number $00 \quad 01$

Chi_UL_Peak 0 - uses default

Chi_UL_Peak 1 - uses default

Chi_UL Peak 2 - uses default

Chi_UL_Peak 3 - uses default

Chi_UL_Peak 4 - uses default

Chi_UL_Peak 5 120.0, 100.0,

$100.0,100.0,100.0,100.0,100.0,100.0,100.0,100.0$, Chi_UL_Peak 6 - uses default 


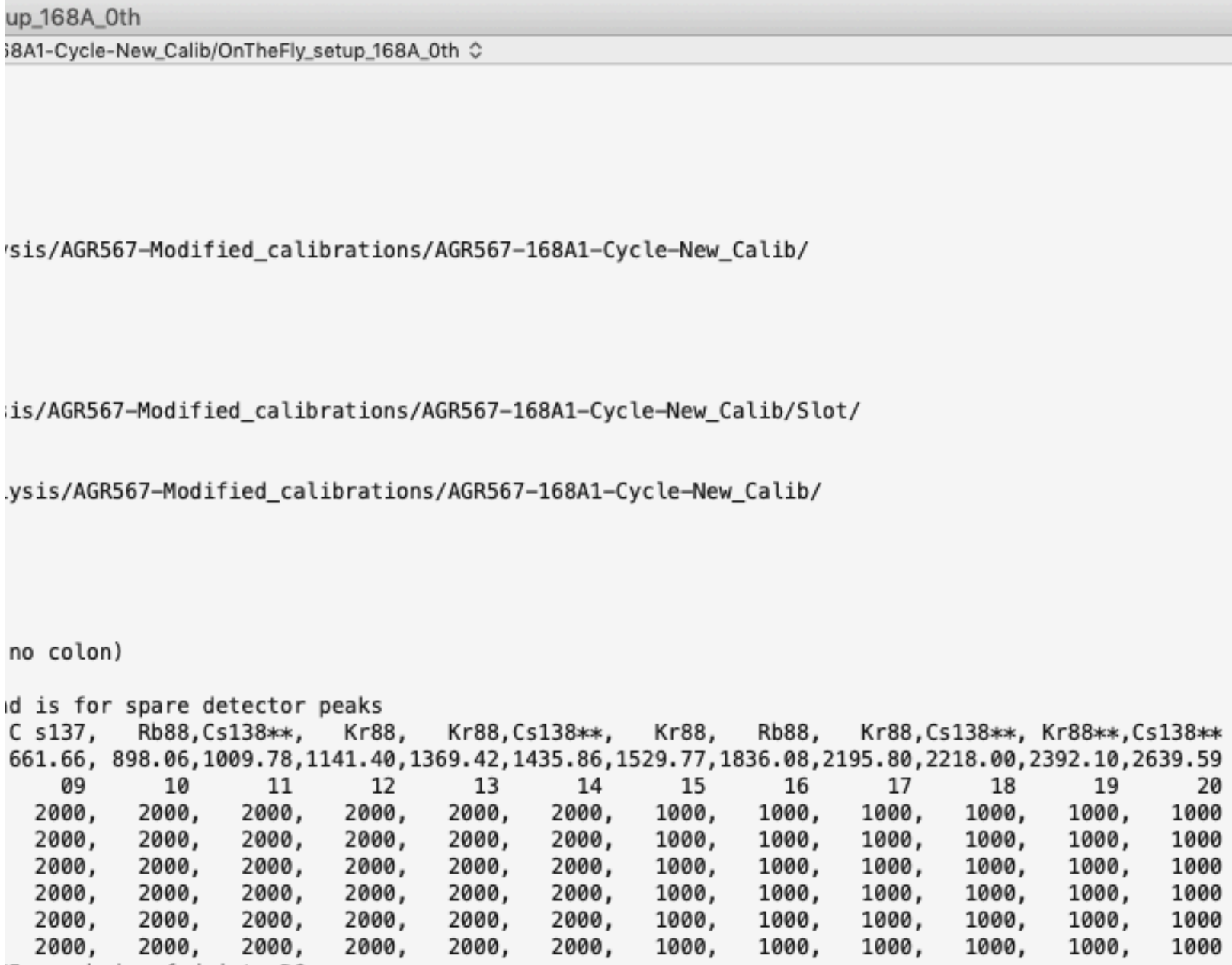

le CHI becomes large 100-200, but still has a good area and centroid

ler energy peaks. Individual detectors can be turned on or all.

$\begin{array}{llllllllllll}09 & 10 & 11 & 12 & 13 & 14 & 15 & 16 & 17 & 18 & 19 & 20\end{array}$

$100.0,100.0,100.0,100.0,100.0,100.0,100.0,100.0,100.0,100.0,100.0,100.0$ 


\section{Appendix D \\ Sample Spectrum GA1309240300.DGE}
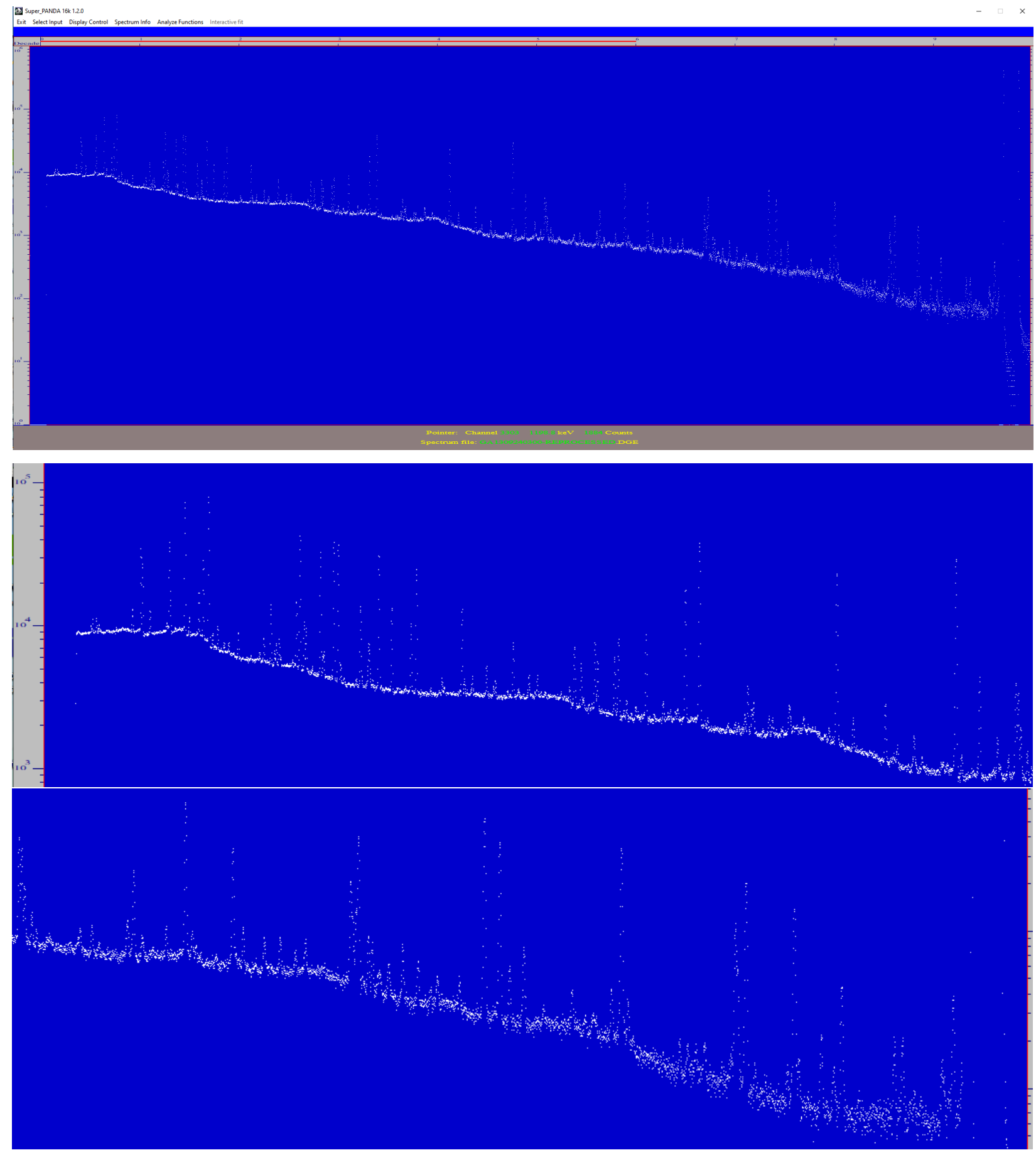


\section{Appendix E \\ Least-Squares Fit of a Quadratic Curve}

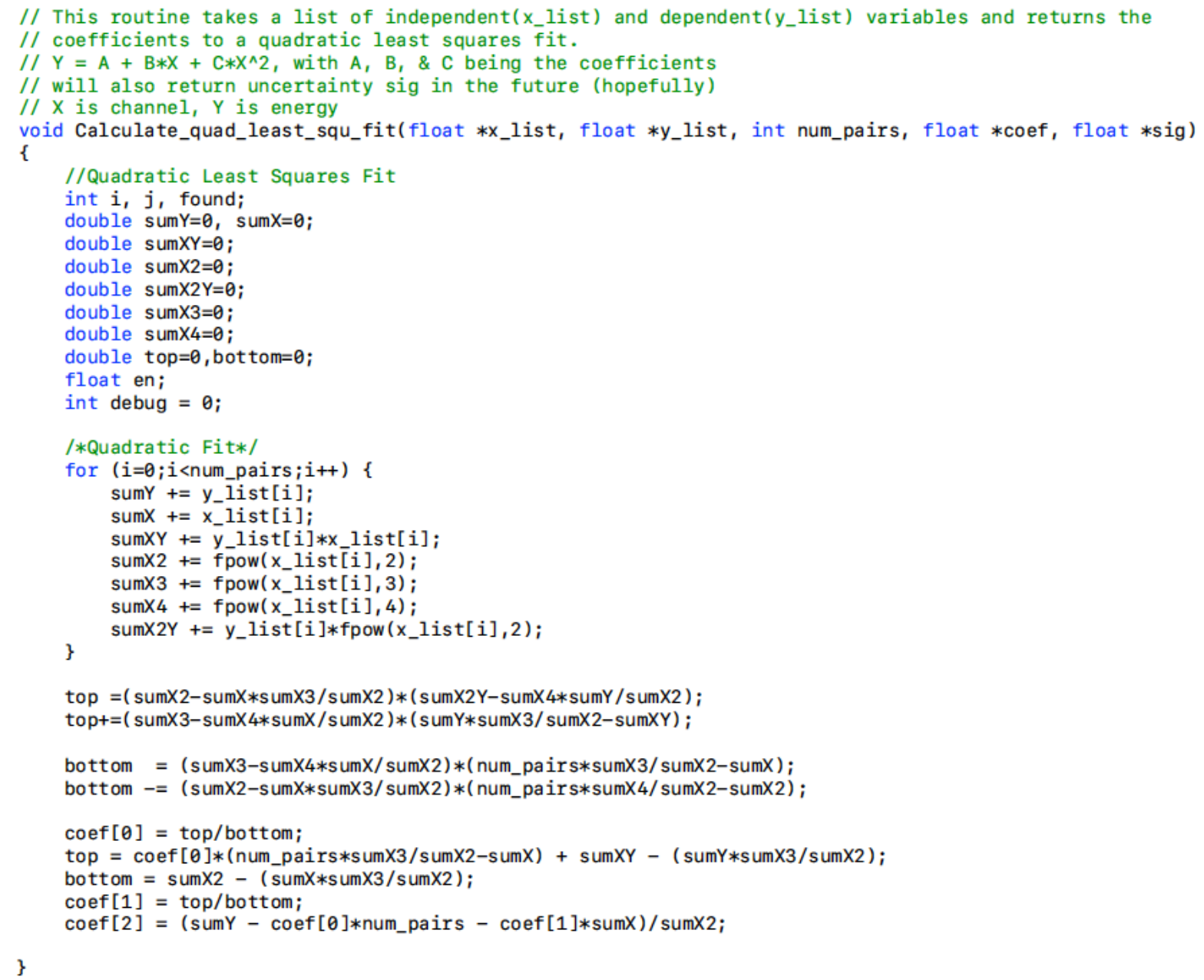

